\title{
Effects of Milling pH and Hydrothermal Treatment on Formation of Nanostructured Boehmite Binder for Alumina Extrusion
}

\author{
Maurício Batista de Lima, ${ }^{1}$ Marcela Bergamaschi Tercini, ${ }^{1}$ Sydney Ferreira Santos, ${ }^{1}$ \\ Fernando dos Santos Ortega, ${ }^{2}$ and Humberto Naoyuki Yoshimura ${ }^{1}$ \\ ${ }^{1}$ Center for Engineering, Modeling and Applied Social Sciences, Federal University of ABC, Av. dos Estados 5001, \\ 09210-580 Santo André, SP, Brazil \\ ${ }^{2}$ Centro Universitário da FEI, Department of Materials Engineering, Av. Humberto Alencar Castelo Branco 3972, \\ 09850-901 São Bernardo do Campo, SP, Brazil \\ Correspondence should be addressed to Humberto Naoyuki Yoshimura; humberto.yoshimura@ufabc.edu.br
}

Received 27 March 2017; Accepted 31 May 2017; Published 5 July 2017

Academic Editor: Victor M. Castaño

Copyright ( 2017 Maurício Batista de Lima et al. This is an open access article distributed under the Creative Commons Attribution License, which permits unrestricted use, distribution, and reproduction in any medium, provided the original work is properly cited.

\begin{abstract}
The in situ formation of nanostructured aluminum hydroxides on the surface of alumina particles, which can work as inorganic binder, was reported in this paper. The effect of the suspension $\mathrm{pH}$ during milling of alumina powder and subsequent hydrothermal treatment for the hydroxide formation and microstructure was depicted. Under acidic $\mathrm{pH}$ condition, the formation of hydroxides was not observed. When the $\mathrm{pH}$ of suspension changed from acidic to basic during milling, bayerite $\left[\mathrm{Al}(\mathrm{OH})_{3}\right]$ nanoparticles were formed, but only a fraction of this hydroxide was converted to boehmite (AlOOH) during subsequent hydrothermal treatment. The aluminum hydroxide and oxyhydroxide formed in this condition improved the smoothness of extruded rods and the strength of presintered segments. For the powder milled under basic $\mathrm{pH}$ condition, the mechanochemically formed bayerite was completely converted into boehmite nanoparticles during the hydrothermal treatment. The presence of boehmite nanoparticles contributed to improving plasticity during extrusion, which allowed the reduction of organic binder and increased the strength of presintered alumina rods.
\end{abstract}

\section{Introduction}

Nowadays, the development of green manufacturing processes with reduced environmental impacts, rational consumption of energy, minimum waste of material, and low emission of pollutants is a critical concern. Among the several actions that may contribute to achieving the abovementioned goals, the use of low-toxicity materials and recycling plays a major role [1]. With regard to ceramic processing, environmental impacts may be reduced in many ways, such as the development of rapid sintering processes, new additives to decrease the temperature of powder synthesis, replacement of toxic organic solvents used in forming methods (such as tape casting and powder injection molding) by aqueous systems, development of manufacturing routes with fewer steps, and elimination or reduction of organic binders (e.g., PVA, PEG, PMMA, and PVB) [2-4].

Organic (polymeric) binders have been used to provide adequate rheological behavior to the ceramic powders during the forming step and mechanical strength to the formed green bodies. The amounts of these additives can reach $10 \mathrm{vol} \%$ or more, depending on the forming method and binding system employed [4]. Organic binders are transient processing additives that decompose during the firing step, generating potentially harmful hydrocarbon gases (e.g., $\mathrm{C}_{3} \mathrm{H}_{5}, \mathrm{C}_{4} \mathrm{H}_{5} \mathrm{O}$, and $\mathrm{C}_{5} \mathrm{H}_{8} \mathrm{O}_{2}$ ) and $\mathrm{CO}_{2}$ which, once released to the atmosphere, contribute to the greenhouse effect [5]. Such environmental impact can be reduced by replacing the organics by inorganic binders, such as boehmite (aluminum oxyhydroxide, $\gamma$-AlOOH), which generates only water as gaseous byproduct $[6,7]$. The addition of boehmite 
nanoparticles to ceramic powders can produce pastes with adequate extrusion behaviors (plasticity and liquid retention capacity) resulting in formed bodies with characteristics (green density and strength) similar to those obtained for pastes containing plastic clays $[7,8]$. Boehmite has also been used as a processing additive in other forming methods, such as sol-gel, cold isostatic pressing, and slurry compaction [911].

The mechanical activation route, also known as mechanochemical synthesis, has received significant attention in recent years to prepare nanoparticles, modify the structure of the particle surface, and synthesize inorganic and organic compounds at room temperature [12-16]. It is usually performed in ball mills, where the compressive and shearing forces exerted by the balls impacts during milling or grinding induce a variety of reactions in the material, such as the formation of crystal defects (e.g., Schottky and Frenkel defects in oxides), amorphization, and phase transformations [12, 17]. Mechanochemical synthesis has been used to obtain complex oxides, metastable phases, nanoparticles with core-shell configurations, and nanometric crystallites formed on the surface of the milled particles (nanocrystalline coatings), which are difficult to synthesize by conventional methods [14-17]. Depending on the materials chemistry, desired microstructure, milling environment, and other processing parameters, different mechanisms might play a role in mechanical activation and these are not yet fully elucidated because direct monitoring of the transformations during milling is difficult. Particularly, there is little information published on the role of water in the mechanochemical treatments (wet ball milling) $[12,13]$.

Milling alumina powders in aqueous media is a possible route to modify the surface of alumina particles by the in situ formation of aluminum trihydroxides surface layers (bayerite $\left[\alpha-\mathrm{Al}(\mathrm{OH})_{3}\right]$ and gibbsite $\left[\gamma-\mathrm{Al}(\mathrm{OH})_{3}\right]$, depending on the $\mathrm{pH}$ of suspension) $[18,19]$. The aluminum hydroxides formed by mechanochemical modification of the surface of alumina particles can be converted to boehmite by a hydrothermal treatment, resulting in pastes with adequate plasticity for extrusion tests and extruded segments with high strength, allowing the reduction of organic binder content [20]. In this work, the effect of $\mathrm{pH}$ on the formation of aluminum hydroxides on the surface of alumina particles during wet milling is investigated. Also, the efficiency of these hydroxides as inorganic binders for extrusion is evaluated.

\section{Experimental}

The starting powder used in the experiments was an unground low-soda calcined alumina (CL 2500, Almatis), indicated by the manufacturer for electronic components such as substrates.

Ceramic suspensions were prepared adding $100 \mathrm{~g}$ of deionized water to $100 \mathrm{~g}$ of alumina powder $(20.1 \mathrm{vol} \%$ of solids). Each suspension was ball milled at $90 \mathrm{rpm}$ during $10 \mathrm{~h}$ using an alumina jar. As grinding media, $2.6 \mathrm{~kg}$ of yttriastabilized tetragonal zirconia polycrystal (Y-TZP) balls of three diameters was used, in the following mass ratio: $24 \%$ of $\phi 5 \mathrm{~mm}$; $49 \%$ of $\phi 15 \mathrm{~mm}$; and $27 \%$ of $\phi 25 \mathrm{~mm}$.
The $\mathrm{pH}$ of the suspensions before milling was measured with a pH-meter (B374, Micronal) and was 9.2. The first milling was conducted without any $\mathrm{pH}$ control and, after milling, the $\mathrm{pH}$ had increased to 10.3. This condition was named basic $\mathrm{pH}$ milling. The second milling was performed after the addition of $1.70 \mathrm{~mL}$ of $\mathrm{HCl}$ solution (50 wt\%) to the suspension, without any additional control of $\mathrm{pH}$, with initial value of 4.1. After this milling, the $\mathrm{pH}$ value increased to 8.4 and this condition was named acidic-basic milling. The third milling was identical to the second milling except for three stops to add $\mathrm{HCl}$ to maintain the $\mathrm{pH}$ low. A total of $5.0 \mathrm{~mL}$ of $\mathrm{HCl}$ solution was added so that the final $\mathrm{pH}$ of this suspension was 4.2. This condition was named acidic $\mathrm{pH}$ milling.

The milled powders were dried in air at $100^{\circ} \mathrm{C}$. Then, $60 \mathrm{~g}$ of each powder was mixed with $30 \mathrm{~g}$ of distilled and deionized water in a porcelain crucible. Afterwards, the mixtures were hydrothermally treated at $150^{\circ} \mathrm{C}$ and $3 \mathrm{~atm}$ for $3 \mathrm{~h}$ using an autoclave (Fabbe Primar).

The starting powder, milled powders, and hydrothermally treated powders were analyzed using the following techniques:

(i) Chemical analysis by X-ray fluorescence spectrometry (XRF 1800, Shimadzu).

(ii) X-ray diffraction, XRD (X'Pert Pro, PANalytical); the measurements were performed using $\mathrm{CuK} \alpha$ radiation with counting time of $10 \mathrm{~s}$ at scanning step of $0.02^{\circ}$.

(iii) Fourier transform infrared (FTIR) spectroscopy (Nicolet Magna 550, Thermo Fisher Scientific) in transmission mode with 49 scans/min and step of $2 \mathrm{~cm}^{-1}$; for this analysis, $0.002 \mathrm{~g}$ of powder was hand mixed with $0.2 \mathrm{~g}$ of $\mathrm{KBr}$ powder using an agate mortar and then pressed with $98 \mathrm{kN}$ load to form a disc with $13 \mathrm{~mm}$ in diameter.

(iv) Particle size analysis using a laser diffraction granulometer (LS 100Q, Coulter Beckman) with particles dispersed in water; before analysis, the suspensions were deagglomerated with an ultrasonic probe of $100 \mathrm{~W}$

(v) Specific surface area analysis by BET (BrunauerEmmett-Teller) method; the nitrogen gas sorption isotherms were measured using a surface area analyzer (Gemini VII 2390, Micromeritics); the powders were degassed under vacuum at $200^{\circ} \mathrm{C}$ for $24 \mathrm{~h}$ before the testing.

(vi) Scanning electron microscopy, SEM (JSM T330-A, Jeol), transmission electron microscopy, TEM, and scanning transmission electron microscopy (STEM) using a field emission gun (FEG) microscope (Tecnai $\left.\mathrm{G}^{2} \mathrm{~F} 20, \mathrm{FEI}\right)$ operating at $200 \mathrm{kV}$.

(vii) Differential scanning calorimetry and thermogravimetry, DSC/TGA, using a simultaneous thermal analyzer, STA (SETSYS Evolution, Setaram), with a heating rate of $5^{\circ} \mathrm{C} / \mathrm{min}$ and synthetic air as atmosphere.

The performance of generated aluminum hydroxides as inorganic binder for alumina was evaluated by means of 
an extrusion test. Some pastes were prepared by adding carboxymethyl cellulose, CMC (Lamcol MMS, Lamberti), to the treated powders as supplementary binder. For each powder, pastes with $0,1.0,1.5$, and $2.0 \mathrm{wt} \%$ of CMC were prepared. First, $10 \mathrm{~g}$ of milled and hydrothermally treated powders was hand mixed with a solution of CMC (10 wt\%) in distilled water. The total water content was set at $18 \mathrm{wt} \%$ of the mass of alumina powder for all pastes (a preliminary study indicated that this content was adequate to prepare pastes with consistency close to that of the ball clay). The homogenized pastes were allowed to age for $48 \mathrm{~h}$ in a closed plastic bag. Afterwards, the plasticity of prepared pastes was evaluated using a stainless-steel pin-barrel extrusion device, with barrel and die diameters of 16 and $3 \mathrm{~mm}$, respectively (reduction in area of 96\%) [21]. Force was applied to the piston at a crosshead speed of $5 \mathrm{~mm} / \mathrm{min}$ in a universal testing machine (3336, Instron).

The extruded segments $(3.1 \mathrm{~mm}$ in diameter and $20 \mathrm{~mm}$ in length) were presintered in an electric furnace (model 1612, Jung) at $1100^{\circ} \mathrm{C}$ for $1 \mathrm{~h}$, after a debinding step at $500^{\circ} \mathrm{C}$ for $1 \mathrm{~h}$, with heating and cooling rates of 5 and $10^{\circ} \mathrm{C} / \mathrm{min}$, respectively. The surface of the extruded sample was evaluated using an optical stereo microscope (SZ61, Olympus), and the strength of the segments was determined using a four-point fully articulated flexure device (with outer and inner spans of 12 and $6 \mathrm{~mm}$, resp.) in the universal testing machine, at a crosshead speed of $0.5 \mathrm{~mm} / \mathrm{min}$.

\section{Results and Discussion}

3.1. Starting and Milled Powders. Chemical analysis by XRF spectroscopy showed that the starting alumina powder (CL 2500, Almatis) had a purity of $99.7 \% \mathrm{Al}_{2} \mathrm{O}_{3}$ and impurities of $0.07 \% \mathrm{Na}_{2} \mathrm{O}, 0.07 \% \mathrm{CaO}, 0.05 \% \mathrm{TiO}_{2}, 0.04 \% \mathrm{Fe}_{2} \mathrm{O}_{3}$, $0.04 \% \mathrm{MgO}$, and $0.03 \% \mathrm{P}_{2} \mathrm{O}_{5}$ (in wt\%). XRD and FTIR spectroscopy showed that $\alpha-\mathrm{Al}_{2} \mathrm{O}_{3}$ was the only detected phase. The powder consisted of strong agglomerates with hundreds of micrometers in size and primary particles of few micrometers, connected by strong sintering bonds forming necking between particles, typical of unground calcined powders (Figure 1(a)).

After ball milling, the hard agglomerates were crushed and resulted in discrete faceted particles, typical of ground ceramic powders, in the range of submicrometric to micrometric sizes. No significant differences were observed between the powders milled under different $\mathrm{pH}$ conditions (acidic, acidic-basic, and basic medium) when analyzed by SEM (Figures 1(b)-1(d)). However, XRD analysis and FTIR spectroscopy revealed that the powder milled under acidic ( $\mathrm{pH} 4.0-4.2$ ) condition had only $\alpha-\mathrm{Al}_{2} \mathrm{O}_{3}$ phase (ICSD 85137), as the starting powder, while the powders milled under acidic-basic ( $\mathrm{pH}$ 4.1-8.4) and basic ( $\mathrm{pH}$ 9.2-10.3) conditions presented small fractions of bayerite $\left[\alpha-\mathrm{Al}(\mathrm{OH})_{3}\right.$, ICSD 38108], in addition to $\alpha$-alumina (Figure 2(a)). The presence of this aluminum trihydroxide was confirmed by FTIR spectroscopy (Figure 2(b)). The absorption bands at $3370,3425,3470,3547,3620$, and $3654 \mathrm{~cm}^{-1}$ were assigned as vibration frequencies of the $\mathrm{OH}$ stretching modes of
$\alpha-\mathrm{Al}(\mathrm{OH})_{3}$ and are in accordance with reported FTIR spectrum data for bayerite [22-25].

Similar mechanochemical transformation of alumina particles during milling has been reported. For an $\alpha-\mathrm{Al}_{2} \mathrm{O}_{3}$ powder ground in water at $\mathrm{pH} 8$ using a high-energy stirred media mill, the amount of transformed aluminum trihydroxides increased with the milling time; after short milling $(2 \mathrm{~h})$ only bayerite (4.6\%) was formed, but for longer milling times, gibbsite was also observed (after $8 \mathrm{~h}, 9.5 \%$ bayerite and 5\% gibbsite) [19]. Besides $\mathrm{pH}$ of suspension and milling time, the type of mill also affects the hydration of alumina. It has been shown that wet milling of an $\alpha-\mathrm{Al}_{2} \mathrm{O}_{3}$ powder in a ball mill and a planetary ball mill resulted in formation of bayerite and gibbsite, while no transformation occurred when a jetmill was used. The relative amounts of formed trihydroxides varied with the milling type: ball milling $(24 \mathrm{~h})$ resulted in more gibbsite, and planetary ball milling $(5 \mathrm{~h})$ resulted in the formation of more bayerite [18]. These reports indicate the complexity of mechanochemical transformation of alumina during milling, which depends on the $\mathrm{pH}$ of suspension, milling time, type of mill, and other milling conditions (water content, slurry-to-ball ratio, ball size, etc.).

$\alpha$-Alumina is not the stable phase in contact with water, and the aluminum trihydroxides, $\mathrm{Al}(\mathrm{OH})_{3}$, can be formed by a hydration reaction as follows:

$$
\mathrm{Al}_{2} \mathrm{O}_{3}+3 \mathrm{H}_{2} \mathrm{O} \longrightarrow 2 \mathrm{Al}(\mathrm{OH})_{3}
$$

The $\mathrm{Al}_{2} \mathrm{O}_{3}-\mathrm{H}_{2} \mathrm{O}$ phase diagram indicates that bayerite $[\alpha$ $\mathrm{Al}(\mathrm{OH})_{3}$ ] forms at temperatures up to $100^{\circ} \mathrm{C}$ [26], but the stability of this trihydroxide is controversial and thermodynamic data indicate that, in this condition, gibbsite $[\gamma$ $\left.\mathrm{Al}(\mathrm{OH})_{3}\right]$ is the most stable form of $\mathrm{Al}(\mathrm{OH})_{3}[27,28]$. It was reported that ageing a $\gamma-\mathrm{Al}_{2} \mathrm{O}_{3}$ powder (with specific surface area, SSA, of $140 \mathrm{~m}^{2} / \mathrm{g}$ ) in water with $0.1 \mathrm{M} \mathrm{NaCl}$ for more than one month at $25^{\circ} \mathrm{C}$ resulted in the formation of bayerite [29]. Another study [25] showed that in a $\gamma-\mathrm{Al}_{2} \mathrm{O}_{3}$ powder (SSA of $189 \mathrm{~m}^{2} / \mathrm{g}$ ), suspended in distilled water during a week under continuous stirring at room temperature, different hydroxides were formed depending on the solution $\mathrm{pH}$ (adjusted by addition of $\mathrm{HNO}_{3}$ or $\mathrm{NH}_{3}$ ): at $\mathrm{pH} 4$, no significant change was observed in the $\gamma-\mathrm{Al}_{2} \mathrm{O}_{3}$ powder; but at higher $\mathrm{pH}$ different aluminum trihydroxides were formed. In the acidic condition, at $\mathrm{pH} \mathrm{5,} \mathrm{gibbsite} \mathrm{was} \mathrm{formed} \mathrm{with}$ a small amount of bayerite, and in neutral and basic $\mathrm{pH}$ conditions the predominant phase formed was bayerite (with a small amount of gibbsite at $\mathrm{pH} 7$ and 9 and only bayerite at $\mathrm{pH}$ 11). It was also observed that bayerite started to form only after $24 \mathrm{~h}$ in contact with water at pH 10 [28]. Our results are in good agreement with these reports, since the powder milled under acidic ( $\mathrm{pH}$ 4.0-4.2) condition did not form hydroxides, while the powders milled under acidic-basic $(\mathrm{pH}$ 4.1-8.4) and basic ( $\mathrm{pH} 9.2-10.3$ ) conditions formed bayerite. Moreover, considering the above-mentioned reports, ball milling accelerated the formation of bayerite, since this hydroxide started to form in contact with water in less than $10 \mathrm{~h}$, using an $\alpha-\mathrm{Al}_{2} \mathrm{O}_{3}$ powder, which is more stable than $\gamma$ $\mathrm{Al}_{2} \mathrm{O}_{3}$, and had a lower surface area (SSA $\left.<10 \mathrm{~m}^{2} / \mathrm{g}\right)$. 


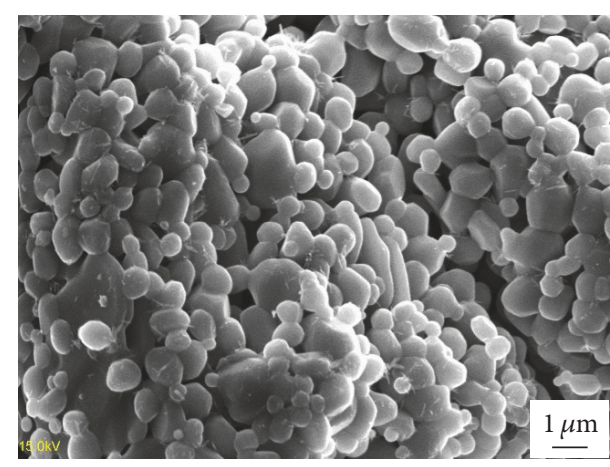

(a)

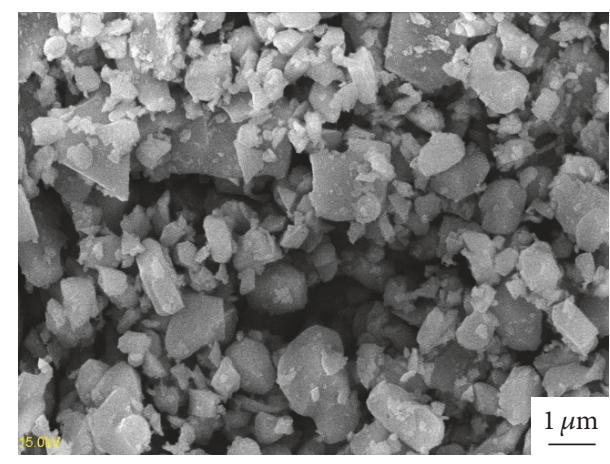

(c)

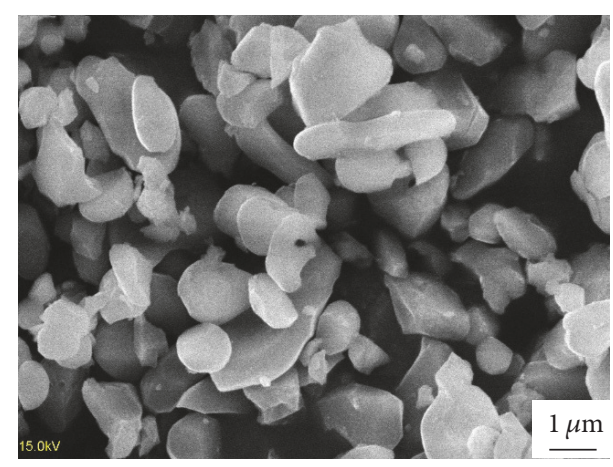

(b)

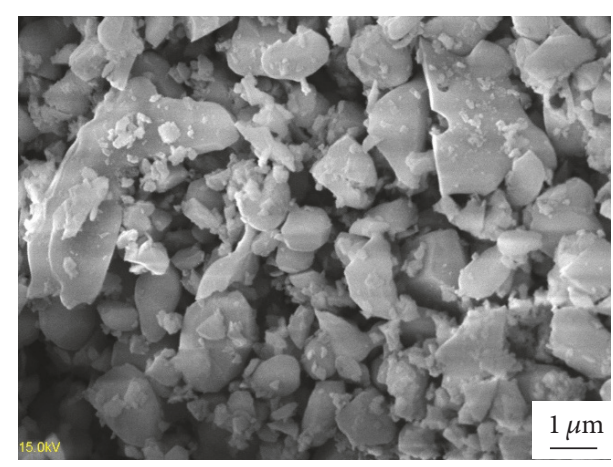

(d)

FIGURE 1: SEM images of starting alumina powder (a) and powders wet milled under acidic (b), acidic-basic (c), and basic (d) pH condition.



(a)

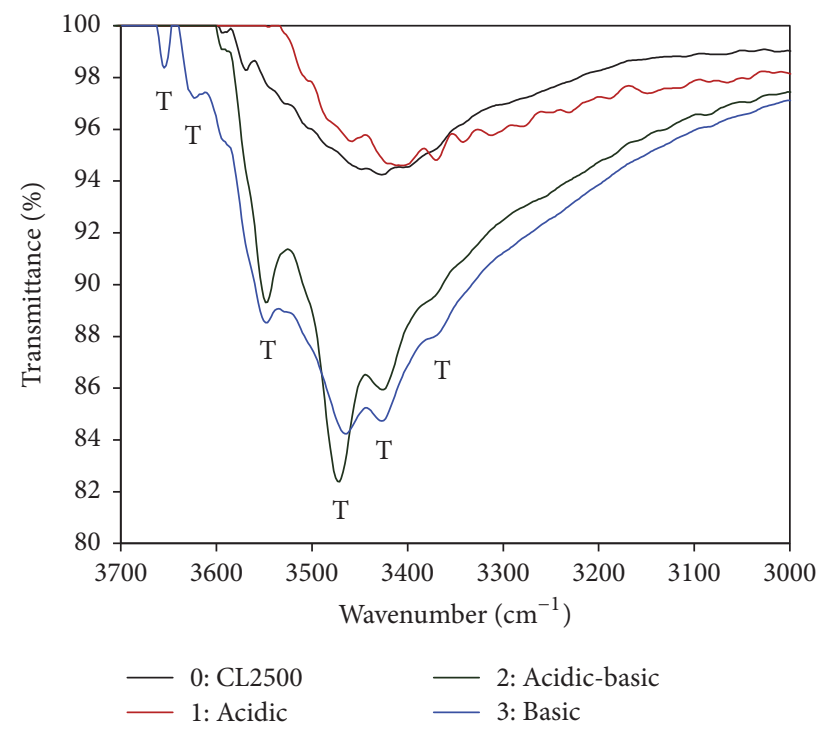

(b)

FIgURE 2: Results of XRD analysis (a) and FTIR spectroscopy (b) of starting powder (0: CL2500) and powders milled under acidic (1), acidic-basic (2), and basic (3) $\mathrm{pH}$ condition. $\mathrm{A}: \alpha-\mathrm{Al}_{2} \mathrm{O}_{3}$; T: bayerite [aluminum trihydroxide $\alpha-\mathrm{Al}(\mathrm{OH})_{3}$ ].

A comparison between the FTIR spectra of the investigated samples revealed that the powder milled under acidicbasic condition had sharper bayerite bands than those of the powder milled under basic pH condition (Figure 2(b)), suggesting the presence of well crystalized bayerite phase in the first powder and a more distorted bayerite structure in the second one. In fact, it has been observed that the increase in milling time for a bayerite powder (using a planetary ball mill in dry condition) resulted in gradual merging of the several $\mathrm{O}-\mathrm{H}$ stretching vibration bands, at around 
$3500 \mathrm{~cm}^{-1}$, into a single broad band. This result indicates that crystalline bayerite had undergone a transformation to amorphous phase. The disorder in the structure was ascribed to the breaking of hydrogen bonds that link the layers of $\mathrm{Al}(\mathrm{OH})_{6}$ octahedra in the bayerite crystal during grinding [30]. The less disordered bayerite structure in the powder milled under acidic-basic condition can be related to the phase transformation during the milling. The studied alumina powder (CL2500) had a basic $\mathrm{pH}$ character, which increased the suspension $\mathrm{pH}$ during the milling, as new surfaces were exposed to the liquid due to the fracture of particles. Once during the milling in acidic-basic condition the $\mathrm{pH}$ increased from 4.1 to 8.4 , probably at the initial stage, in acidic $\mathrm{pH}$; gibbsite or an amorphous hydroxide was formed and gradually transformed to bayerite as the $\mathrm{pH}$ increased. This behavior has been reported in experimental observations of the effects of $\mathrm{pH}$ on the hydration of $\rho$ alumina and $\gamma$-alumina and precipitation studies $[28,31$, 32]. This phase transformation favors the appearance of a recrystallized structure, which eliminates defects previously introduced in the precursor phase (gibbsite); therefore, less defective bayerite crystals were formed. In the basic $(\mathrm{pH}$ 9.2-10.3) condition, it seems that bayerite was formed primarily and subjected to the grinding effect over time, resulting in a disordered structure and broadening of the FTIR spectrum bands.

Figure 3 shows TEM and STEM images of the powders milled under different $\mathrm{pH}$ conditions. The surface of alumina particles milled under acidic $\mathrm{pH}$ condition (Figures 3(a) and 3(b)) had continuous and sharp features, indicating relatively extensive crystalline regions. Small crystallites on the surface of large alumina grains, which might be expected from the hydroxide transformation, were not detected. The observed microstructural features indicated that the mechanochemical transformation did not take place during milling in acidic $\mathrm{pH}$. However, for the powders milled under acidic-basic (Figures $3(\mathrm{c})$ and $3(\mathrm{~d})$ ) and basic (Figure 3(e)) pH conditions, an irregular layer covering the surface of alumina particles was observed. This layer was more electron-transmissive than the original primary particles, which is related to the formation of a coating with lower density than the particles. This coating consisted of nanocrystallites less than $10 \mathrm{~nm}$, some of them equiaxial, while others are of columnar shape, grown from the surface of primary particles. These microstructural features indicate the formation of aluminum trihydroxides, according to the results of XRD and FTIR spectroscopy. Some isolated polycrystalline nanometric agglomerates were also observed in these powders (Figure 3(f)) but were absent in the powder milled under acidic $\mathrm{pH}$ condition. Similar coatings of low density aluminum trihydroxides were also observed in ball milled $\alpha$-alumina powders in other studies [33-35]. These results confirm that hydration occurs on the surface of alumina particles, in a process that is intensified under milling. It has also been proposed that the formation of aluminum trihydroxides can result from the dissolution of alumina and precipitation from a supersaturated solution, leading to the formation of hydroxide crystals away from the alumina surface [28]. In fact, the solubility of alumina and aluminum trihydroxides in water is low in the $\mathrm{pH}$ range from
5 to 8 but increases sharply beyond this range $[19,27,36]$, which makes this mechanism feasible.

3.2. Hydrothermally Treated Powders. The powders milled under different conditions were hydrothermally treated and characterized by XRD and FTIR spectroscopy (Figure 4). As expected, the powder milled under acidic $\mathrm{pH}$ condition had no alteration during the hydrothermal treatment and the XRD pattern indicated only the presence of $\alpha-\mathrm{Al}_{2} \mathrm{O}_{3}$ phase (Figure 4(a)). However, the powder milled under acidic-basic condition presented both bayerite $\left[\alpha-\mathrm{Al}(\mathrm{OH})_{3}\right.$, ICSD 38108] and boehmite ( $\gamma$-AlOOH, ICSD 93734) phases, whereas the powder milled under basic $\mathrm{pH}$ condition had only boehmite, in addition to the main $\alpha-\mathrm{Al}_{2} \mathrm{O}_{3}$ phase, as shown in the XRD patterns and confirmed with the FTIR spectra (Figure 4(b)). The absorption bands at 3090 and $3293 \mathrm{~cm}^{-1}$ were assigned as vibration frequencies of $\mathrm{OH}$ stretching modes (asymmetric and symmetric, resp.) of $\gamma$-AlOOH and are in accordance with the FTIR spectrum data reported for boehmite [37-40]. These results showed that the aluminum trihydroxide formed during ball milling (bayerite) was partially or completely transformed to aluminum oxyhydroxide (boehmite) during the hydrothermal treatment.

Boehmite has been synthesized by hydrothermal treatment of either trihydroxides or solutions, but minimum conditions must be satisfied to achieve full conversion or precipitation. It was demonstrated that the transformation of bayerite to boehmite was incomplete (50\% conversion) under static hydrothermal treatment $\left(180^{\circ} \mathrm{C}, 1 \mathrm{MPa}, 2 \mathrm{~h}\right)$, but it was enhanced under stirring, controlled atmosphere $\left(\mathrm{H}_{2}\right)$, and higher pressure (4 MPa) [41]. For a solution of $\mathrm{Al}\left(\mathrm{NO}_{3}\right)_{3} \cdot 9 \mathrm{H}_{2} \mathrm{O}$ and $\mathrm{NaOH}$ in alkaline medium $(\mathrm{pH}$ 11.6) using an autoclave at $160^{\circ} \mathrm{C}$, it was observed that bayerite was formed in the early stages of precipitation and was later converted to boehmite by dissolution-reprecipitation mechanism; $100 \%$ boehmite was obtained after $5 \mathrm{~h}$ of hydrothermal treatment [42]. Also using a solution of aluminum nitrate, with urea as neutralizing agent, under stirring of $300 \mathrm{rpm}$ in a closed reactor $(0.9 \mathrm{MPa})$, the minimum temperature required for precipitation of the crystalline boehmite was $160^{\circ} \mathrm{C}$ [43].

In this work, the hydrothermal treatment was conducted at $150^{\circ} \mathrm{C}$ and $0.3 \mathrm{MPa}$ during $3 \mathrm{~h}$, without agitation. This setting was not sufficient to achieve the full conversion of bayerite to boehmite for the powder milled under acidic-basic condition. However, under the same conditions, the bayerite present in the powder milled at basic $\mathrm{pH}$ was completely converted to boehmite. This result indicated that the bayerite formed when the $\mathrm{pH}$ is maintained in the basic range during the whole milling process can be more easily transformed to boehmite during autoclaving, which might be related to the more disordered structure of the bayerite formed in this case (broader FTIR absorption bands, Figure 2(b)). It is well known that phase transformations can be accelerated by the reduction of particle size and the presence of crystal defects, which can act as rapid diffusion paths and sites for heterogeneous nucleation $[44,45]$. Thus, mechanochemically induced crystal defects seem to have favored the phase transformation of bayerite to boehmite during the hydrothermal treatment. 




(a)

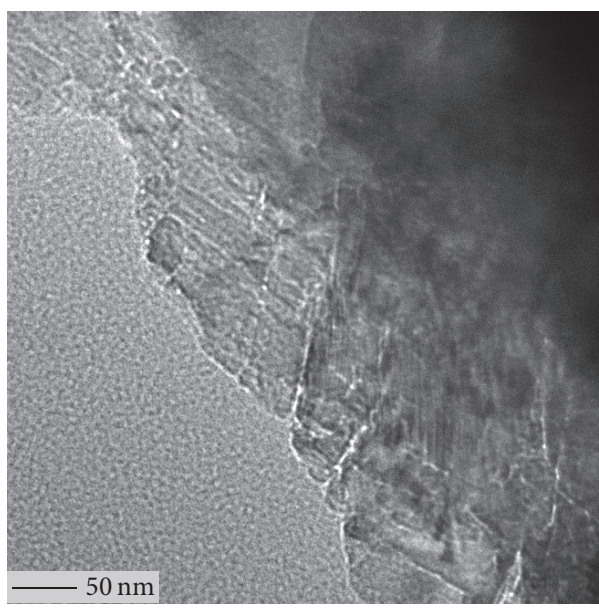

(c)

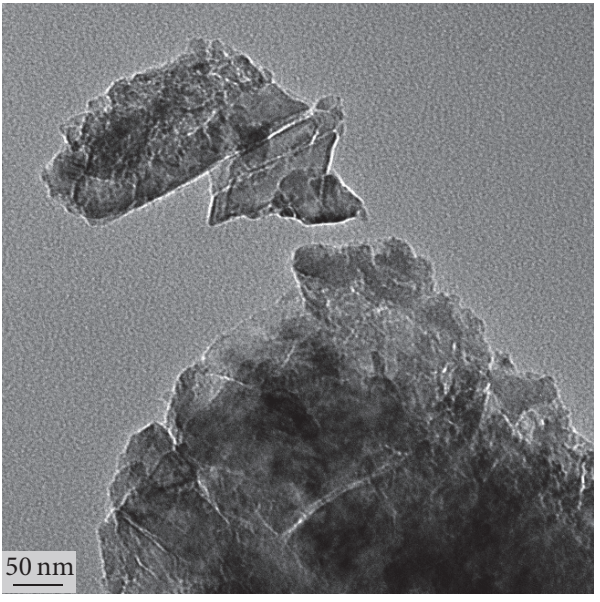

(e)



(b)

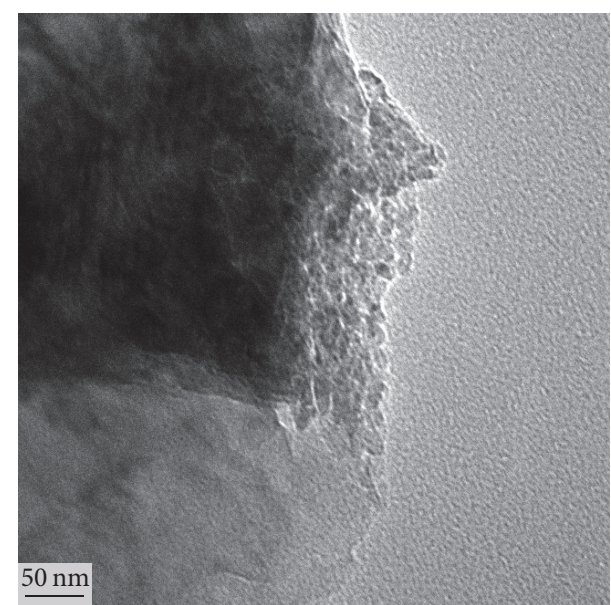

(d)

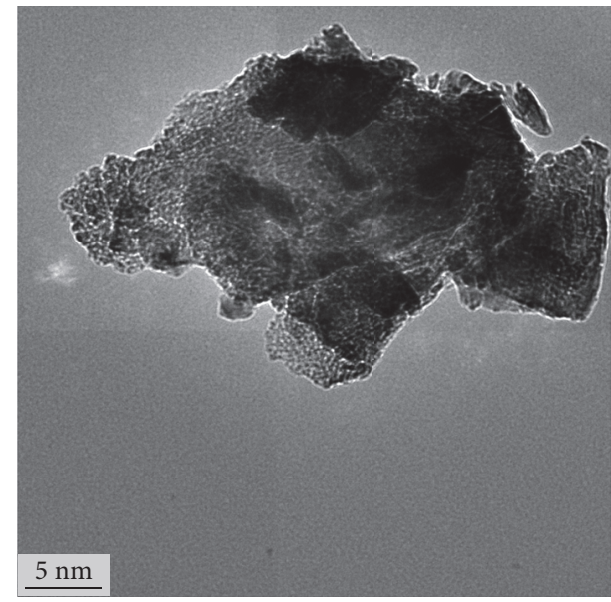

(f)

FIGURE 3: STEM images of the alumina powder milled under acidic $\mathrm{pH}$ condition $(\mathrm{a}, \mathrm{b})$ and TEM images of powders milled under acidic-basic (c, d) and basic (e, f) pH conditions. 


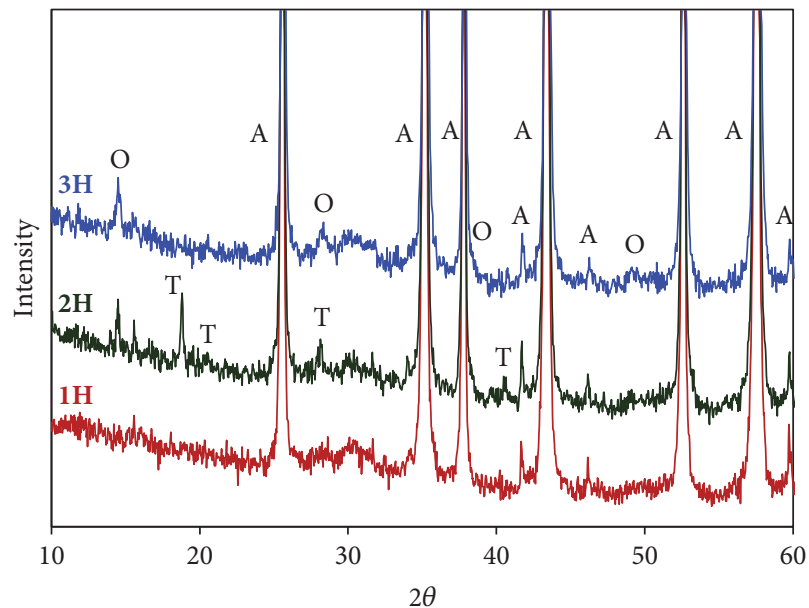

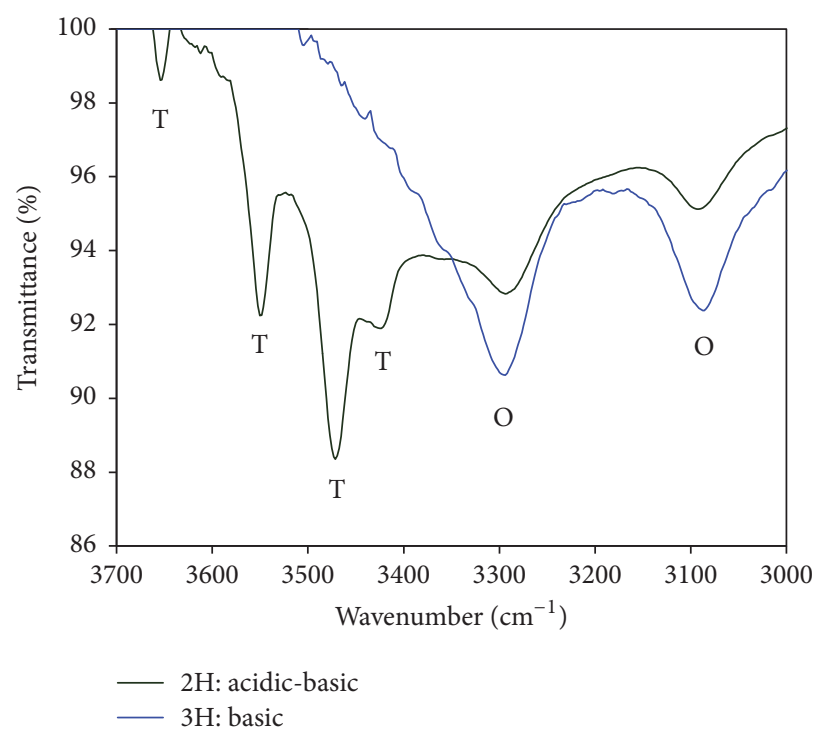

(b)

FIGURE 4: Results of XRD analysis (a) and FTIR spectroscopy (b) of hydrothermally treated powders after milling under acidic (1H), acidic-basic $(2 \mathrm{H})$, and basic $(3 \mathrm{H}) \mathrm{pH}$ condition. $\mathrm{A}: \alpha-\mathrm{Al}_{2} \mathrm{O}_{3}$; T: bayerite [aluminum trihydroxide, $\alpha-\mathrm{Al}(\mathrm{OH})_{3}$; $\mathrm{O}$ : boehmite $($ aluminum oxyhydroxide, $\gamma$-AlOOH).

Figure 5 shows TEM images of hydrothermally treated powders. The powder milled under acidic-basic condition presented a layer of hydroxide on the surface of micrometric alumina particles (Figure 5(a)) as well as some agglomerates of nanometric particles (Figure 5(b)). On the other hand, the powder milled under basic $\mathrm{pH}$ condition had a few nanoparticles covering the alumina particles, but most of them were detached from the surface (Figure 5(c)), forming agglomerates of very fine boehmite particles (Figure 5(d)), as identified by XRD and FTIR spectroscopy analyses (Figure 4). Agglomerates of boehmite nanoparticles with characteristics similar to those shown in Figure 5(c) were observed by TEM analysis, after hydrothermal treatment at $120^{\circ} \mathrm{C}$ of a solution of $\mathrm{Al}\left(\mathrm{NO}_{3}\right)_{3} \cdot 9 \mathrm{H}_{2} \mathrm{O}$ and $\mathrm{NaOH}$ [42]. This feature was taken as an indication that the conversion of bayerite into boehmite would be controlled by dissolution-reprecipitation mechanism, since the topotactic phase transformation is not likely to occur due to different structural forms, $\alpha$ and $\gamma$, of these compounds [42]. Similarly, for the powder milled under acidic-basic condition, it seems that only a fraction of the massive layers of bayerite formed on the surface of alumina particles was converted into boehmite nanoparticles (Figure 5(b)), while the remaining fraction was kept untransformed (Figure 5(a)).

Several hydrothermal synthesis studies have shown that boehmite precipitates can be prepared with different morphologies, varying from one- to three-dimensional shapes, such as nanowires, fibers, laths, nanosheets, microfoils, platelets (with rhombic, hexagonal, or ellipsoid profile), nanoplatelets with spindle-like edges, nanoparticles, (nano)flakes, and flower-like superstructures (with singlecrystals petals), depending on the precursors or reactants, $\mathrm{pH}$, surfactants, and hydrothermal conditions used
[41, 42, 46-50]. In the present work, the hydrothermal treatment of mechanochemically formed bayerite resulted in boehmite nanoparticles with isometric shape (Figure 5(d)).

Table 1 shows the results of particle size distribution and specific surface area (SSA) of milled and hydrothermally treated powders. As noted before (Figure 1), a significant reduction in particle size occurred, since $D_{50}$ changed from $90 \mu \mathrm{m}$ in the starting powder to around $1.65 \mu \mathrm{m}$ after ball milling, regardless of the $\mathrm{pH}$ of the suspension. The powder milled under basic $\mathrm{pH}$ condition had higher SSA $\left(5.25 \mathrm{~m}^{2} / \mathrm{g}\right)$ than the powder milled under acidic-basic condition $\left(4.14 \mathrm{~m}^{2} / \mathrm{g}\right)$, due to its higher content of boehmite nanoparticles after hydrothermal treatment. The powder milled under acidic $\mathrm{pH}$ condition presented the highest SSA $\left(6.71 \mathrm{~m}^{2} / \mathrm{g}\right)$. Nonetheless, this value could not be correlated with the presence of nanoparticles, since no aluminum hydroxides were formed in this powder. Additionally, the particle size distribution was similar for all powders.

Figure 6 shows the results of thermal analyses of milled and hydrothermally treated powders. As expected, no significant thermal events were observed in the powder milled under acidic $\mathrm{pH}$ condition, since it contained only the stable $\alpha-\mathrm{Al}_{2} \mathrm{O}_{3}$ phase. For the powder milled under acidic-basic condition, which had bayerite and boehmite, the weight loss gradually increased during the initial heating, achieving $0.14 \mathrm{wt} \%$ at $238^{\circ} \mathrm{C}$, as a result of water desorption (TGA curve, Figure 6(b)). An abrupt weight loss of $0.20 \mathrm{wt} \%$ was observed between 238 and $265^{\circ} \mathrm{C}$, corresponding to an endothermic peak in the DSC curve (Figure 6(a)) at $257^{\circ} \mathrm{C}$, which was assigned to the decomposition of bayerite. The decomposition temperature of unground bayerite has been reported at around $300^{\circ} \mathrm{C}$, but this temperature can be reduced to temperatures as low as $\sim 130^{\circ} \mathrm{C}$ after long milling 


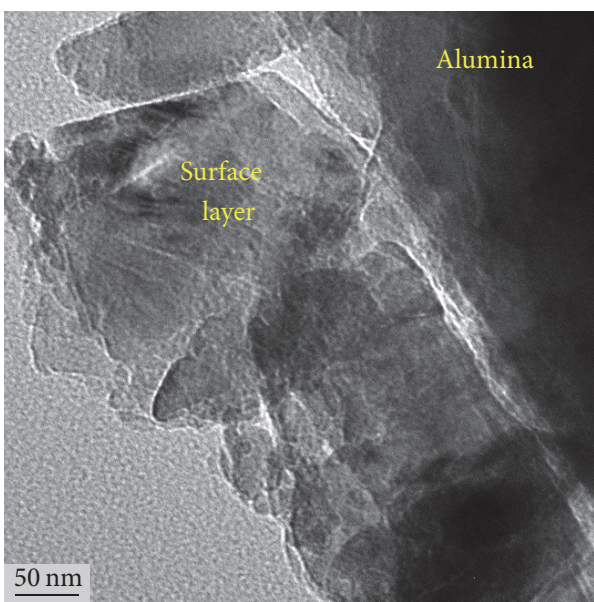

(a)

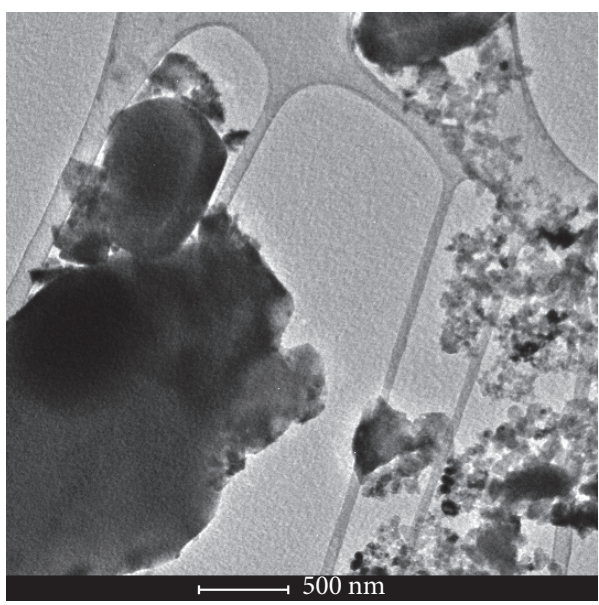

(c)

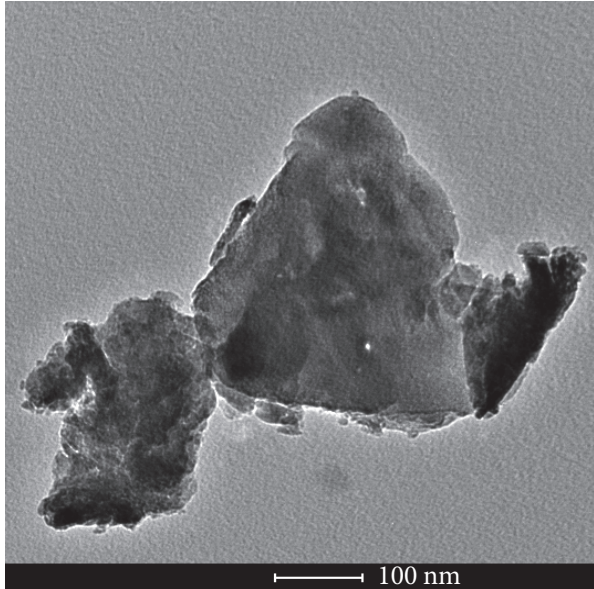

(b)

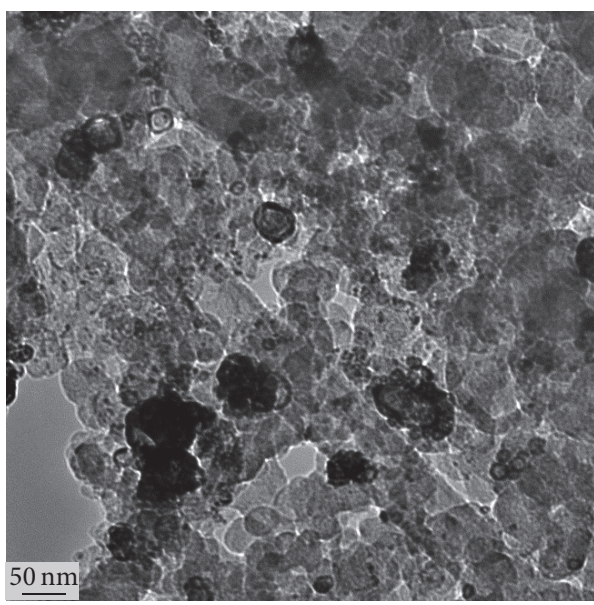

(d)

FIGURE 5: TEM images of hydrothermally treated powders after milling under acidic-basic (a, b) and basic (c, d) pH condition.

TABLE 1: Results of particle size distribution $\left(D_{10}, D_{50}\right.$ and $D_{90}$ are sizes at $10 \%, 50 \%$ and $90 \%$ in the cumulative volume fraction curve, respectively) and specific surface area (SSA) of milled and hydrothermally treated powders.

\begin{tabular}{lcccc}
\hline Milling condition & $D_{10}(\mu \mathrm{m})$ & $D_{50}(\mu \mathrm{m})$ & $D_{90}(\mu \mathrm{m})$ & \\
\hline Acidic $\mathrm{pH}$ & 0.905 & 1.650 & 2.911 & $\mathrm{SSA}\left(\mathrm{m}^{2} / \mathrm{g}\right)$ \\
Acidic-basic & 0.902 & 1.654 & 2.880 & 6.71 \\
Basic $\mathrm{pH}$ & 0.909 & 1.658 & 2.903 & 4.14 \\
\hline
\end{tabular}

periods [30, 41, 51]. Above $265^{\circ} \mathrm{C}$, the weight decreased continuously, reaching a weight loss of $0.57 \mathrm{wt} \%$ at $445^{\circ} \mathrm{C}$, when a new inflection was observed in the TGA curve. Such mass loss is related to a continuous dehydration of bayerite, as has been reported for the thermal decomposition of mechanically activated gibbsite and bayerite [51, 52]. The decomposition reaction of bayerite can be described as [30]

$$
2\left[\alpha-\mathrm{Al}(\mathrm{OH})_{3}\right] \longrightarrow \eta-\mathrm{Al}_{2} \mathrm{O}_{3}+3 \mathrm{H}_{2} \mathrm{O}
$$

Considering the predicted weight loss of $34.6 \mathrm{wt} \%$ for the water evaporation in (2), the weight loss of $0.43 \mathrm{wt} \%$ between 238 and $445^{\circ} \mathrm{C}$ corresponded to a bayerite content of
$1.2 \mathrm{wt} \%$. The weight loss rate increased again between 445 and $490^{\circ} \mathrm{C}$ in TGA curve (Figure 6(b)), although no significant variation in heat flux could be detected in this temperature range for the DSC curve of the powder milled under acidicbasic condition (Figure 6(a)). However, for the powder milled under basic $\mathrm{pH}$ condition, an endothermic peak at $473^{\circ} \mathrm{C}$ was observed, which was assigned to the decomposition of boehmite $[41,46,53]$. Therefore, the weight loss of $0.07 \mathrm{wt} \%$ between 445 and $490^{\circ} \mathrm{C}$ in the powder milled under acidicbasic condition was assigned to the dehydration of boehmite, whe reaction is given by [30]

$$
2(\gamma-\mathrm{AlOOH}) \longrightarrow \gamma-\mathrm{Al}_{2} \mathrm{O}_{3}+\mathrm{H}_{2} \mathrm{O}
$$






FiguRE 6: Results of differential scanning calorimetry, DSC (a), and thermogravimetric analysis, TGA (b), of milled (under different pH conditions) and hydrothermally treated powders.

Considering the theoretical water loss in (3) $(15.0 \mathrm{wt} \%)$, the estimated boehmite fraction was $0.5 \mathrm{wt} \%$ in the powder milled under acidic-basic condition.

For the powder milled under basic $\mathrm{pH}$ condition, which had only boehmite after the hydrothermal treatment, the mass decreased during the initial heating due to the water desorption, achieving $0.14 \mathrm{wt} \%$ of weight loss at $265^{\circ} \mathrm{C}$ (TGA curve, Figure 6(b)). Above this temperature, the weight loss rate gradually increased and almost ceased at $485^{\circ} \mathrm{C}$ (temperature at the end of endothermic peak of the boehmite decomposition, Figure 6(a)). Similar thermogravimetric curves for the decomposition of boehmite have been reported $[41,46]$. In this temperature range $\left(265\right.$ to $\left.485^{\circ} \mathrm{C}\right)$, the weight loss was $0.48 \mathrm{wt} \%$, which corresponded to a boehmite fraction of $3.2 \mathrm{wt} \%$, according to (3). An exothermic peak was observed at $877^{\circ} \mathrm{C}$ in the DSC curve of the powder milled under basic $\mathrm{pH}$ condition, which can be related to the transformation of $\gamma-\mathrm{Al}_{2} \mathrm{O}_{3}$ to $\delta-\mathrm{Al}_{2} \mathrm{O}_{3}$ [30].

In summary, thermal analyses indicated the formation of $1.7 \mathrm{wt} \%$ of aluminum hydroxides $(1.2 \%$ bayerite and $0.5 \%$ boehmite) in the powder milled under acidic-basic condition and $3.2 \mathrm{wt} \%$ of boehmite in the powder milled under basic $\mathrm{pH}$ condition, both after the hydrothermal treatment. These results are in good agreement with those found by transmission electron microscopy, which indicated the presence of more nanoparticles in the powder milled under basic $\mathrm{pH}$.
3.3. Extrusion Behavior of Treated Powders. The behavior during the extrusion of pastes prepared with milled and hydrothermally treated alumina powders varied significantly, depending on the milling $\mathrm{pH}$, as shown in Figure 7. Pastes prepared only with water addition did not develop the plasticity required for extrusion. The force applied on the piston gradually increased as the piston moved, reaching $2.0 \mathrm{kN}$ after the displacement of $10 \mathrm{~mm}$. Above this point, the force increased rapidly, exceeding $50 \mathrm{kN}$ at the end of the test (Figure $7(\mathrm{a})$ ). The steady increase in force is associated with the occurrence of water exudation during extrusion, known as liquid phase migration [54-58]. The water retention capacity is important to maintain the layer of lubricating liquid between the ceramic particles during the forming process. Thus, as the amount of water in the paste was reduced, the force required to push the extruded segment increased. In fact, water droplets were observed leaking from the junctions of extrusion device during the extrusion test, and an almost-dried powder compact remained in the barrel of extrusion device after the test.

The pastes prepared with the addition of $1.0 \mathrm{wt} \%$ of CMC also showed significant water migration for the powders milled under acidic and acidic-basic $\mathrm{pH}$ conditions, in accordance with the continuous increase of the extrusion force as a function of the piston displacement (Figure 7(b)). The plasticity of pastes prepared with these powders was 


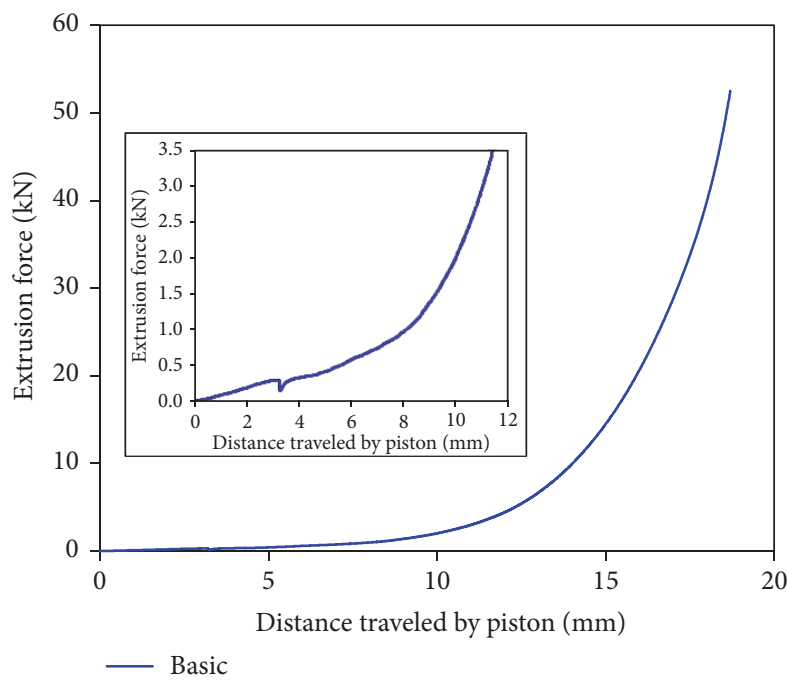

(a)

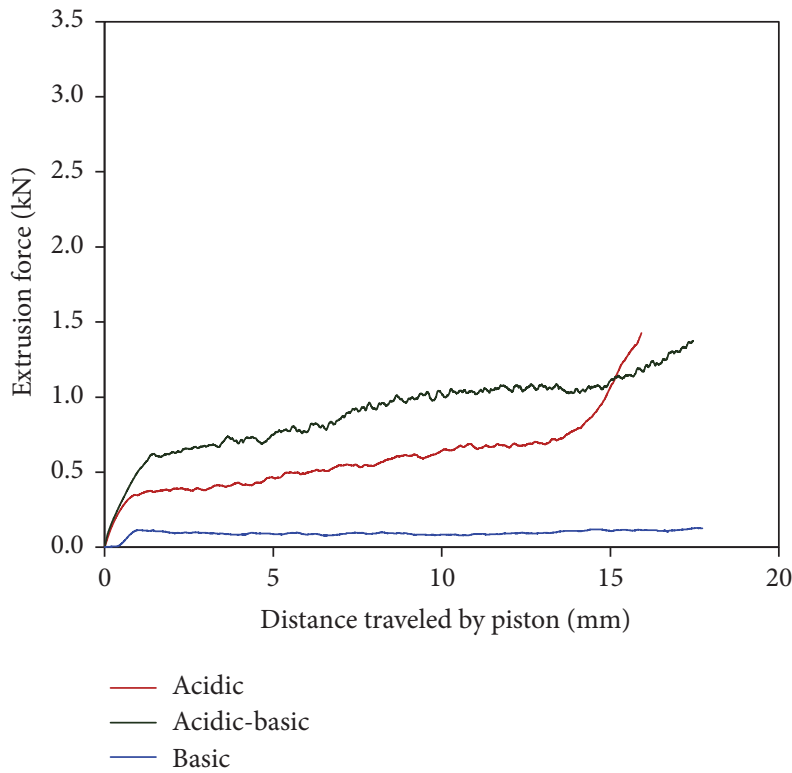

(c)

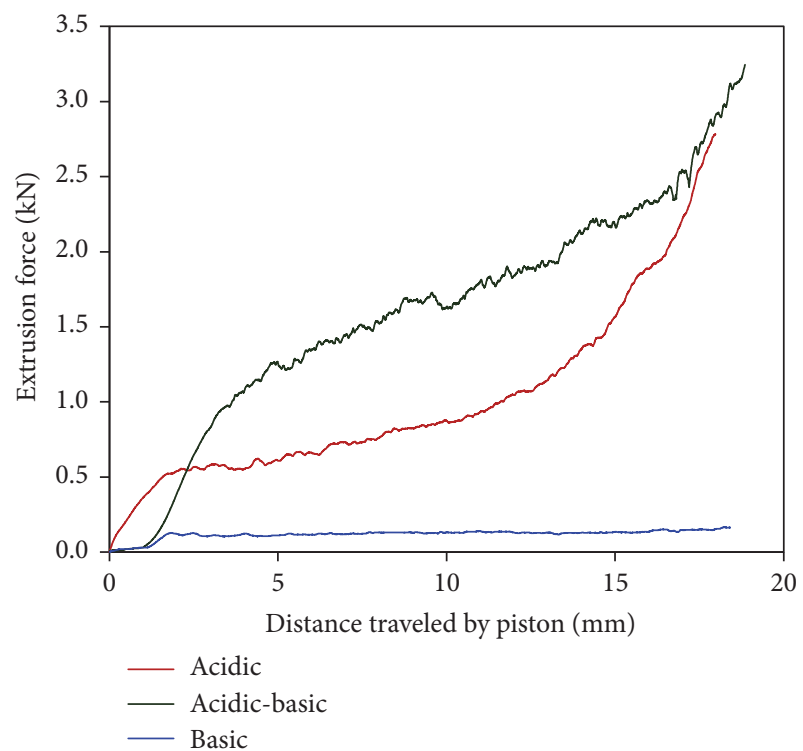

(b)

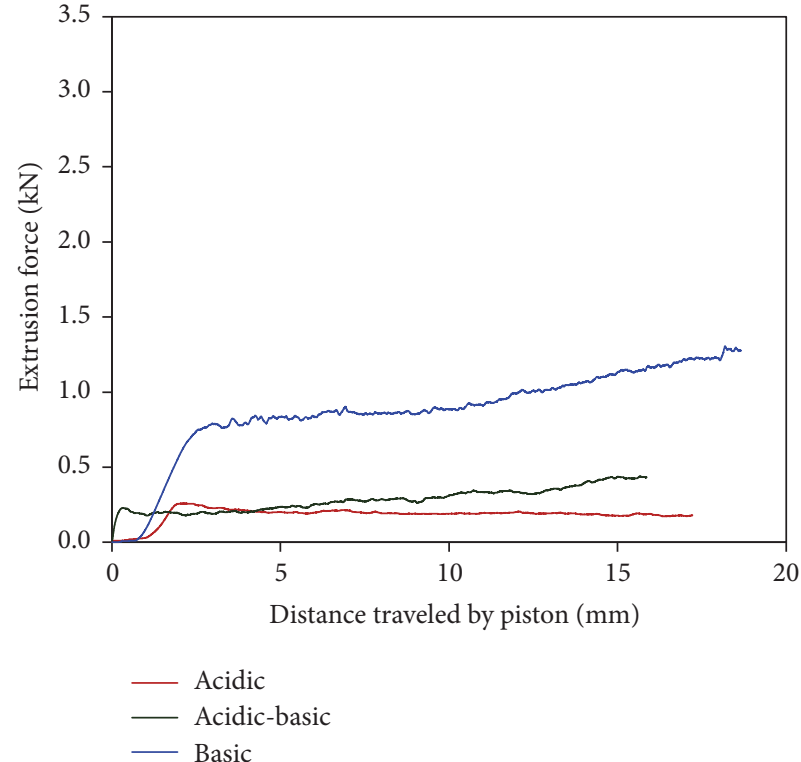

(d)

FIGURE 7: Results of extrusion tests (force as a function of distance traveled by the piston) of the pastes prepared with treated powders (milled under different $\mathrm{pH}$ conditions and hydrothermally treated) and different amounts of CMC content: (a) $0 \mathrm{wt} \%$, (b) $1.0 \mathrm{wt} \%$, (c) $1.5 \mathrm{wt} \%$, and (d) $2.0 \mathrm{wt} \%$.

improved by increasing the CMC content. After addition of $1.5 \mathrm{wt} \% \mathrm{CMC}$, the migration of water and the extrusion force were reduced, even though for either powder a steady state of constant force along the piston displacement was not reached (Figure 7(c)). At piston displacement of $10 \mathrm{~mm}$, the extrusion force values were 0.9 and $0.6 \mathrm{kN}$ for the powder milled under acidic $\mathrm{pH}$ condition with 1.0 and $1.5 \mathrm{wt} \%$ of $\mathrm{CMC}$, respectively, while for the powder milled under acidicbasic condition the force values were higher $(1.6$ and $1.0 \mathrm{kN}$, resp.).

On the other hand, the pastes prepared with the powder milled under basic $\mathrm{pH}$ condition and addition of 1.0 and
$1.5 \mathrm{wt} \%$ of CMC presented a plateau of constant extrusion force of $0.1 \mathrm{kN}$ during the tests (Figures $7(\mathrm{~b})$ and $7(\mathrm{c})$ ). These results showed that the boehmite nanoparticles imparted plasticity to the alumina powder, improving the water retention during the extrusion when low amounts of organic (CMC) binder were added. The beneficial effects of boehmite are related to the nanometric dimensions of particles and the shear capacity of its layered crystal structure, which is similar to plastic clays [59].

The addition of $2.0 \mathrm{wt} \%$ of CMC changed the extrusion behavior of all powders. The pastes prepared with the powders milled under acidic and acidic-basic $\mathrm{pH}$ conditions 


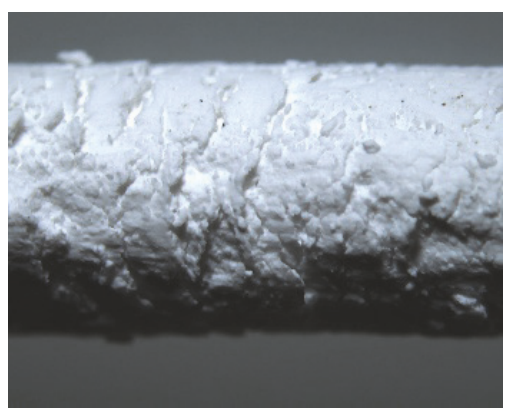

(a)

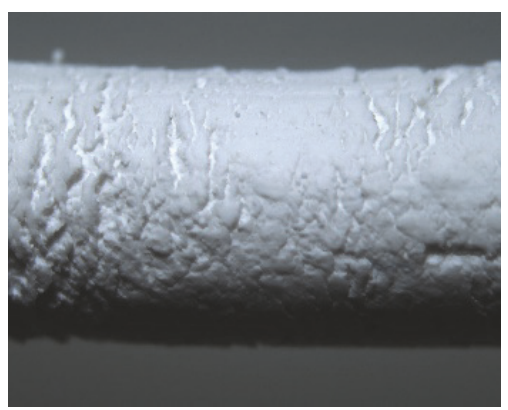

(d)

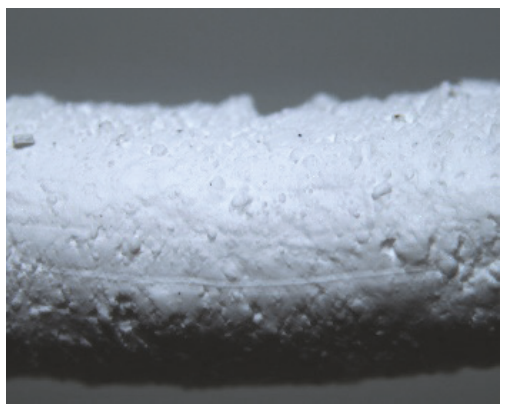

(g)

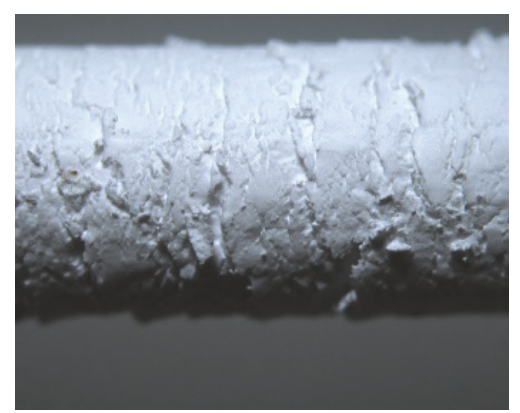

(b)

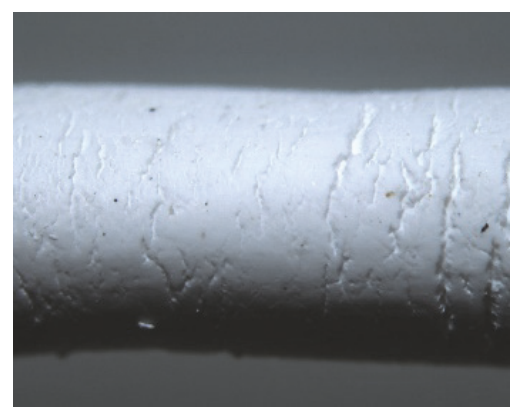

(e)

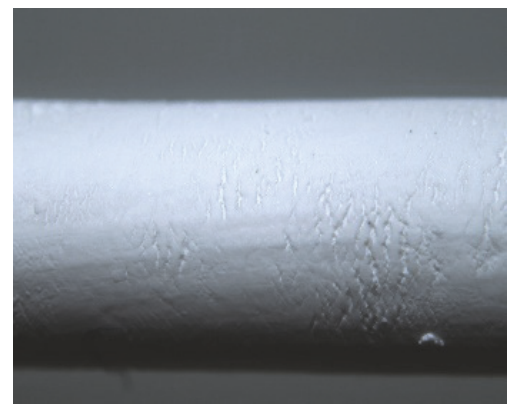

(h)

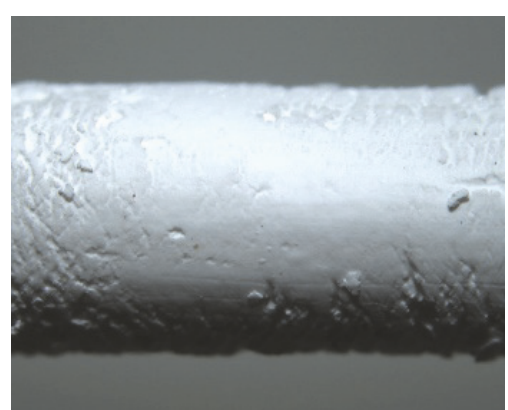

(c)

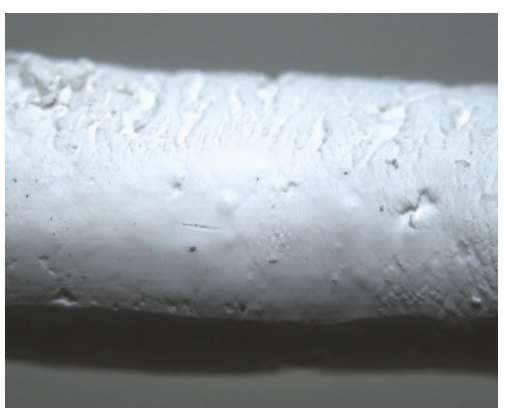

(f)

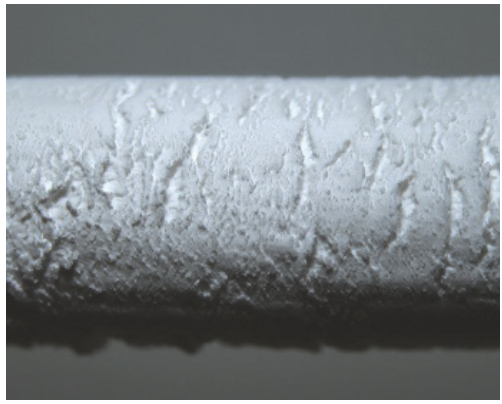

(i)

Figure 8: Optical microscopy images showing the surface of extruded rods prepared with the treated powders: (a, b, c) 1.0\% CMC; (d, e, f) 1.5\% CMC; (g, h, i) 2.0\% CMC; (a, d, g) acidic; (b, e, h) acidic-basic; (c, f, i) basic pH milling. The diameter of rods is $3.1 \mathrm{~mm}$.

achieved the stationary regime with almost constant extrusion forces of 0.2 and $0.3 \mathrm{kN}$, respectively (Figure $7(\mathrm{~d})$ ). However, for the paste prepared with the powder milled under basic $\mathrm{pH}$ condition, the extrusion force increased and reached $0.9 \mathrm{kN}$ at the piston displacement of $10 \mathrm{~mm}$, revealing that an excessive addition of CMC binder in the presence of boehmite is deleterious to the extrusion behavior of the paste.

It has been shown that the addition of $\sim 11 \mathrm{wt} \%$ of colloidal boehmite and $0.3 \mathrm{wt} \%$ of PVA to $\alpha-\mathrm{Al}_{2} \mathrm{O}_{3}$ powders yields pastes with good plasticity, water retention, and the ability to flow under an applied constant force of $\sim 1 \mathrm{kN}$ in extrusion tests [8]. Another work demonstrated that the addition of organic binders $(0.25 \mathrm{wt} \%$ of PVA, $3.0 \mathrm{wt} \%$ of either PEG or glycerin) to an alumina paste containing $15 \mathrm{wt} \%$ of boehmite helped to achieve a very low extrusion pressure, similar to that observed using a conventional binder system (HPMC polymer) [60]. In the present work, the alumina powder milled under basic $\mathrm{pH}$ condition had only $3.2 \mathrm{wt} \%$ of boehmite nanoparticles, but such low amount of boehmite, associated with a small fraction of organic binder ( $1.0 \mathrm{wt} \% \mathrm{CMC}$ ), was sufficient to prepare a paste with adequate rheology and low extrusion pressure. These results showed that the boehmite nanoparticles generated in situ by mechanochemical and hydrothermal treatments are very effective as inorganic processing aid for extrusion of alumina powders. Moreover, this processing route can decrease by $50 \%$ the content of organic binder used in the forming processes, with a potential to reduce the environmental impact caused by its thermal decomposition.

The surface finish of extruded rods prepared with the treated powders was varied, as observed by optical microscopy (Figure 8). For the extrusion tests that showed a plateau of constant extrusion force with the piston displacement, the extruded rods had relatively smooth surfaces (e.g., Figure 8(c)), but when this regime was not reached, the rods had rough surfaces and edge tearing-periodic surface 


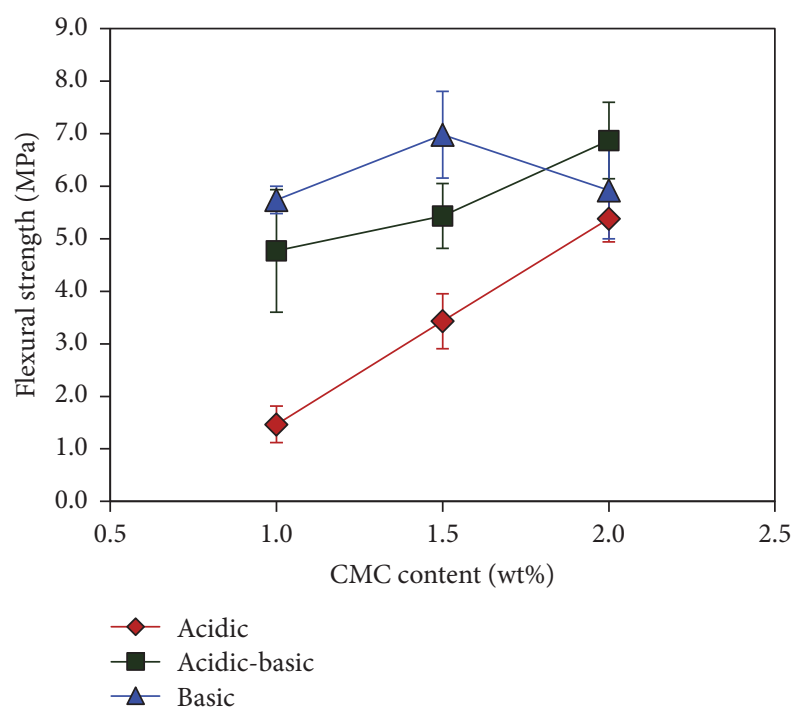

FIGURE 9: Results of four-point flexural strength of the presintered segments extruded with treated powders as a function of added CMC content.

cracks were formed (e.g., Figure 8(a)) [55]. This type of defect occurs because of the poor paste plasticity, the high extrusion force, and the liquid migration. Although the powder milled under acidic-basic condition did not present a reduction of the extrusion force at the level presented by the powder milled under basic $\mathrm{pH}$ condition, the extruded rods had smoother surfaces (Figure 8(h)) than the rods prepared with the powder milled under acidic $\mathrm{pH}$ condition (Figure $8(\mathrm{~g})$ ). This result indicated the beneficial effect of the presence of nanoparticles ( $1.2 \mathrm{wt} \%$ bayerite and $0.5 \mathrm{wt} \%$ boehmite) on decreasing the friction between the extruded alumina rod and the die surface.

The extruded rods had no shrinkage after presintering at $1100^{\circ} \mathrm{C}$, which means that their strength resulted only from the neck formation between particles during the initial stage of sintering and from the surface quality of the extruded segments [61]. Figure 9 shows the results of four-point bending strength of the presintered samples as a function of CMC content added for extrusion. For segments prepared with the powder milled under acidic $\mathrm{pH}$ condition, the strength increased with CMC content (1.5 to $5.4 \mathrm{MPa}$ ), because of the improvement of surface smoothness. A similar tendency was observed for the segments prepared with the powder milled under acidic-basic condition, but with higher values of strength ( 4.8 to $6.9 \mathrm{MPa}$ ). These results indicated that, besides the surface quality, the presence of aluminum hydroxide nanoparticles also contributed to increasing the strength, since they enhanced the neck formation between alumina particles during the presintering treatment. The segments with the highest strength $(7.0 \mathrm{MPa})$ were those prepared with the powder milled under basic $\mathrm{pH}$ condition and $1.5 \% \mathrm{CMC}$, which were benefited by the two effects, associated with the presence of boehmite nanoparticles: the batch had good plasticity, resulting in smooth surface, and the neck formation between alumina particles was enhanced [20].
The results showed that boehmite nanoparticles formed by mechanical activation and subsequent hydrothermal treatment can improve the plastic behavior of alumina pastes during extrusion, reducing the content of organic binder and increasing the strength of formed and presintered bodies.

\section{Conclusions}

The $\mathrm{pH}$ of suspension during the ball milling of alumina powder affects the formation of aluminum hydroxides on the surface of particles. Under acidic $\mathrm{pH}$ (4.0-4.2), the formation of hydroxides was not observed. When the milling medium naturally changed from acidic $(\mathrm{pH} 4.1)$ to basic ( $\mathrm{pH}$ 8.4) during milling, bayerite $\left[\mathrm{Al}(\mathrm{OH})_{3}\right]$ nanoparticles were formed, of which only a small fraction was converted to boehmite $(\mathrm{AlOOH})$ during the hydrothermal treatment; thermal analyses indicated formation of $1.2 \mathrm{wt} \%$ of bayerite and $0.5 \mathrm{wt} \%$ of boehmite. The aluminum hydroxides formed in this condition improved the smoothness of the extruded rods and the strength of presintered segments; nonetheless, they were not able to prevent water migration during the extrusion process. For the powder milled under basic $\mathrm{pH}$ (9.2-10.3) condition, the mechanochemically formed bayerite was completely converted to boehmite nanoparticles during the hydrothermal treatment, resulting in $3.2 \mathrm{wt} \%$ of boehmite in the alumina powder. The boehmite nanoparticles contributed to the development of plasticity, which allowed the reduction of the organic binder. Additionally, the strength of the presintered segments was increased.

\section{Disclosure}

The authors declare that an earlier version of this work was presented as a poster at the 7th Latin American Conference on Metastable and Nanostructured Materials (NANOMAT) 2017.

\section{Conflicts of Interest}

The authors declare that there are no conflicts of interest regarding the publication of this paper.

\section{Acknowledgments}

The authors acknowledge the Brazilian agency CNPq (Grant nos. 481743/2012-0 and 402289/2013-7) for the financial support of the present research.

\section{References}

[1] A. M. Deif, "A system model for green manufacturing," Advances in Production Engineering \& Management, vol. 6, pp. 27-36, 2011.

[2] C. Duran, K. Sato, Y. Hotta, T. Nagaoka, and K. Watari, "Eco-friendly processing and methods for ceramic materials-a review," Journal of the Ceramic Society of Japan, vol. 116, pp. 11751181, 2008.

[3] A. L. Molisani and H. N. Yoshimura, "Low-temperature synthesis of AlN powder with multicomponent additive systems 
by carbothermal reduction-nitridation method," Materials Research Bulletin, vol. 45, no. 6, pp. 733-738, 2010.

[4] J. S. Reed, Principles of Ceramics Processing, Wiley-Interscience, New York, NY, USA, 2nd edition, 1995.

[5] T. Nagaoka, T. Tsugoshi, Y. Hotta, M. Yasuoka, and K. Watari, "Forming and sintering of porous calcium-hexaaluminate ceramics with hydraulic alumina," Journal of Materials Science, vol. 41, no. 22, pp. 7401-7405, 2006.

[6] S. Ananthakumar and K. G. K. Warrier, "Extrusion characteristics of alumina-aluminium titanate composite using boehmite as a reactive binder," Journal of the European Ceramic Society, vol. 21, no. 1, pp. 71-78, 2001.

[7] S. Ananthakumar, A. R. R. Menon, K. Prabhakaran, and K. G. K. Warrier, "Rheology and packing characteristics of alumina extrusion using boehmite gel as a binder," Ceramics International, vol. 27, no. 2, pp. 231-237, 2001.

[8] A. Y. Chen and J. D. Cawley, "Extrusion of $\alpha-\mathrm{Al}_{2} \mathrm{O}_{3}$-boehmite mixtures," Journal of the American Ceramic Society, vol. 75, no. 3, pp. 575-579, 1992.

[9] B. Kindl, D. J. Carlsson, Y. Deslandes, and J. M. A. Hoddenbagh, "Preparation of $\alpha$-alumina ceramics: the use of boehmite sols as dispersing agents," Ceramics International, vol. 17, no. 6, pp. 347-350, 1991.

[10] S. Kwon and G. L. Messing, "Constrained densification in boehmite-alumina mixtures for the fabrication of porous alumina ceramics," Journal of Materials Science, vol. 33, no. 4, pp. 913-921, 1998.

[11] S. Ananthakumar, V. Raja, and K. G. K. Warrier, "Effect of nanoparticulate boehmite sol as a dispersant for slurry compaction of alumina ceramics," Materials Letters, vol. 43, no. 4, pp. 174-179, 2000.

[12] P. Baláž, M. Achimovičová, M. Baláž et al., "Hallmarks of mechanochemistry: from nanoparticles to technology," Chemical Society Reviews, vol. 42, no. 18, pp. 7571-7637, 2013.

[13] J. L. Do and T. Friščić, "Mechanochemistry: a force of synthesis," ACS Central Science, vol. 3, no. 1, pp. 13-19, 2017.

[14] J. Huot, D. B. Ravnsbæk, J. Zhang, F. Cuevas, M. Latroche, and T. R. Jensen, "Mechanochemical synthesis of hydrogen storage materials," Progress in Materials Science, vol. 58, no. 1, pp. 30-75, 2013.

[15] S. F. Santos, J. F. R. De Castro, T. T. Ishikawa, and E. A. Ticianelli, "Effect of mechanical coating with $\mathrm{Ni}$ and $\mathrm{Ni}-5 \% \mathrm{Al}$ on the structure and electrochemical properties of the $\mathrm{Mg}-50 \% \mathrm{Ni}$ alloy," Journal of Materials Science, vol. 43, no. 8, pp. 2889-2894, 2008.

[16] S. F. Santos, T. T. Ishikawa, W. J. Botta, and J. Huot, " $\mathrm{MgH}_{2}+$ FeNb nanocomposites for hydrogen storage," Materials Chemistry and Physics, vol. 147, no. 3, pp. 557-562, 2014.

[17] V. Šepelák, A. Düvel, M. Wilkening, K.-D. Becker, and P. Heitjans, "Mechanochemical reactions and syntheses of oxides," Chemical Society Reviews, vol. 42, no. 18, pp. 7507-7520, 2013.

[18] Y. Hotta, T. Shirai, K. Sato, H. Yilmaz, and K. Watari, "Hydrodynamic interaction of particles in $\mathrm{Al}_{2} \mathrm{O}_{3}$ slurries prepared by different milling methods," Journal of the American Ceramic Society, vol. 92, no. 6, pp. 1198-1202, 2009.

[19] F. Stenger, S. Mende, J. Schwedes, and W. Peukert, "The influence of suspension properties on the grinding behavior of alumina particles in the submicron size range in stirred media mills," Powder Technology, vol. 156, no. 2-3, pp. 103-110, 2005.

[20] H. N. Yoshimura and M. B. Lima, "Ecofriendly alumina processing with in situ formed nanostructured boehmite binder," Materials Letters, vol. 137, pp. 293-296, 2014.
[21] T. Nagaoka, K. Sato, Y. Hotta, T. Tsugoshi, and K. Watari, "Extrusion of alumina ceramics with hydraulic alumina without organic additives," Nippon Seramikkusu Kyokai Gakujutsu Ronbunshi/Journal of the Ceramic Society of Japan, vol. 115, no. 1339, pp. 191-194, 2007.

[22] D. H. Lee and R. A. Condrate Sr., "An FTIR spectral investigation of the structural species found on alumina surfaces," Materials Letters, vol. 23, no. 4-6, pp. 241-246, 1995.

[23] R. L. Frost, J. T. Kloprogge, S. C. Russell, and J. L. Szetu, "Vibrational spectroscopy and dehydroxylation of aluminum (oxo)hydroxides: gibbsite," Applied Spectroscopy, vol. 53, no. 4, pp. 423-434, 1999.

[24] P. Raharjo, C. Ishizaki, and K. Ishizaki, "Surface hydration states of high purity $\alpha-\mathrm{Al}_{2} \mathrm{O}_{3}$ powders," Journal of the Ceramic Society of Japan, vol. 108, no. 5, pp. 449-455, 2000.

[25] N. Koga, T. Fukagawa, and H. Tanaka, "Preparation and thermal decomposition of synthetic bayerite," Journal of Thermal Anal$y$ sis and Calorimetry, vol. 64, no. 3, pp. 965-972, 2001.

[26] L. P. Cook, "Phase equilibria of alumina," in Alumina chemicals: science and technology handbook, L. D. Hart, Ed., pp. 49-71, The American Ceramic Society, Columbus, Ohio, USA, 1990.

[27] K. Wefers, "Nomenclature, preparation, and properties of aluminum oxides, oxide hydroxides, and trihydroxides," in Alumina chemicals: science and technology handbook, The American Ceramic Society, L. D. Hart, Ed., pp. 13-22, The American Ceramic Society, Columbus, Ohio, USA, 1990.

[28] X. Carrier, E. Marceau, J.-F. Lambert, and M. Che, "Transformations of $\gamma$-alumina in aqueous suspensions. 1. Alumina chemical weathering studied as a function of $\mathrm{pH}$," Journal of Colloid and Interface Science, vol. 308, no. 2, pp. 429-437, 2007.

[29] E. Laiti, P. Persson, and L. O. Ohman, "Balance between surface complexation and surface phase transformation at the alumina/water interface," Langmuir, vol. 14, no. 4, pp. 825-831, 1998.

[30] T. Tsuchida and N. Ichikawa, "Mechanochemical phenomena of gibbsite, bayerite and boehmite by grinding," Reactivity of Solids, vol. 7, no. 3, pp. 207-217, 1989.

[31] S. D. Vaidya and N. V. Thakkar, "Study of phase transformations during hydration of rho alumina by combined loss on ignition and x-ray diffraction technique," Journal of Physics and Chemistry of Solids, vol. 62, no. 5, pp. 977-986, 2001.

[32] X. Du, Y. Wang, X. Su, and J. Li, "Influences of $\mathrm{pH}$ value on the microstructure and phase transformation of aluminum hydroxide," Powder Technology, vol. 192, no. 1, pp. 40-46, 2009.

[33] Y. Hotta, H. Yilmaz, T. Shirai, K. Ohota, K. Sato, and K. Watari, "State of the dispersant and particle surface during wetjet milling for preparation of a stable slurry," Journal of the American Ceramic Society, vol. 91, no. 4, pp. 1095-1101, 2008.

[34] Y. Hotta, K. Tsunekawa, T. Shirai, K. Sato, M. Yasuoka, and K. Watari, "Fabrication of stable $\mathrm{Al}_{2} \mathrm{O}_{3}$ slurries and dense green bodies using soft-energy milling process," Journal of the European Ceramic Society, vol. 29, no. 5, pp. 869-874, 2009.

[35] K. Sato, Y. Hotta, H. Yilmaz, K. Sato, and K. Watari, "Fluidity of methyl cellulose-contained suspensions and pastes prepared from differently milled $\mathrm{Al}_{2} \mathrm{O}_{3}$ powder," Journal of Colloid and Interface Science, vol. 331, no. 1, pp. 221-226, 2009.

[36] G. V. Franks and Y. Gan, "Charging behavior at the aluminawater interface and implications for ceramic processing," Journal of the American Ceramic Society, vol. 90, no. 11, pp. 33733388, 2007. 
[37] J. D. Russell, V. C. Farmer, and D. G. Lewis, "Lattice vibrations of boehmite $(\gamma-\mathrm{AlOOH})$ : Evidence for a $\mathrm{C}^{12}{ }_{2 \mathrm{v}}$ rather than a $\mathrm{D}^{17}{ }_{2 \mathrm{~h}}$ space group," Spectrochimica Acta Part A: Molecular Spectroscopy, vol. 34, no. 12, pp. 1151-1153, 1978.

[38] A. B. Kiss, G. Keresztury, and L. Farkas, "Raman and Irspectra and structure of boehmite $(\gamma-\mathrm{AlOOH})$ - evidence for the recently discarded $\mathrm{D}^{17}{ }_{2 \mathrm{~h}}$ space group," Spectrochimica Acta, vol. 36, no. 7, pp. 653-658, 1980.

[39] R. Tettenhorst and D. A. Hofmann, "Crystal chemistry of boehmite," Clays and Clay Minerals, vol. 28, no. 5, pp. 373-380, 1980.

[40] G. K. Priya, P. Padmaja, K. G. K. Warrier, A. D. Damodaran, and G. J. Aruldhas, "Dehydroxylation and high temperature phase formation in sol-gel boehmite characterized by Fourier transform infrared spectroscopy," Journal of Materials Science Letters, vol. 16, no. 19, pp. 1584-1587, 1997.

[41] J. Q. Wang, J. L. Liu, X. Y. Liu, M. H. Qiao, Y. Pei, and K. N. Fan, "Hydrothermal transformation of bayerite to boehmite," Science of Advanced Materials, vol. 1, no. 1, pp. 77-85, 2009.

[42] S. Musić, D. Dragčević, S. Popović, and N. Vdović, "Microstructural properties of boehmite formed under hydrothermal conditions," Materials Science and Engineering B, vol. 52, no. 2-3, pp. 145-153, 1998.

[43] D. Mishra, S. Anand, R. K. Panda, and R. P. Das, "Hydrothermal preparation and characterization of boehmites," Materials Letters, vol. 42, no. 1, pp. 38-45, 2000.

[44] D. A. Porter and K. E. Easterling, Phase Transformations in Metals and Alloys, Chapman \& Hall, London, UK, 2nd edition, 1992.

[45] C. Suryanarayana, "Mechanical alloying and milling," Progress in Materials Science, vol. 46, no. 1-2, pp. 1-184, 2001.

[46] X. Bokhimi, J. Sànchez-Valente, and F. Pedraza, "Crystallization of sol-gel boehmite via hydrothermal annealing," Journal of Solid State Chemistry, vol. 166, no. 1, pp. 182-190, 2002.

[47] Y. Liu, D. Ma, X. Han et al., "Hydrothermal synthesis of microscale boehmite and gamma nanoleaves alumina," Materials Letters, vol. 62, no. 8-9, pp. 1297-1301, 2008.

[48] P. de Souza Santos, A. C. V. Coelho, H. de Souza Santos, and P. K. Kiyohara, "Hydrothermal synthesis of well-crystallised boehmite crystals of various shapes," Materials Research, vol. 12, no. 4, pp. 437-445, 2009.

[49] Y. Deng, Q. Yang, G. Lu, and W. Hu, "Synthesis of $\gamma$-Al2O3 nanowires through a boehmite precursor route," Ceramics International, vol. 36, no. 6, pp. 1773-1777, 2010.

[50] G. Rani and P. D. Sahare, "Effect of temperature on structural and optical properties of boehmite nanostructure," International Journal of Applied Ceramic Technology, vol. 12, no. 1, pp. 124-132, 2015.

[51] N. Koga, "A comparative study of the effects of decomposition rate control and mechanical grinding on the thermal decomposition of aluminum hydroxide," Journal of Thermal Analysis and Calorimetry, vol. 81, no. 3, pp. 595-601, 2005.

[52] K. J. D. MacKenzie, J. Temuujin, and K. Okada, "Thermal decomposition of mechanically activated gibbsite," Thermochimica Acta, vol. 327, no. 1-2, pp. 103-108, 1999.

[53] G. Li, J. Smith, H. Inomata, and K. Arai, "Synthesis and thermal decomposition of nitrate-free boehmite nanocrystals by supercritical hydrothermal conditions," Materials Letters, vol. 53, no. 3, pp. 175-179, 2002.

[54] J. J. Benbow, E. W. Oxley, and J. Bridgwater, "The extrusion mechanics of pastes-the influence of paste formulation on extrusion parameters," Chemical Engineering Science, vol. 42, no. 9, pp. 2151-2162, 1987.

[55] A. B. Yu, J. Bridgwater, A. S. Burbidge, and Z. Saracevic, "Liquid maldistribution in particulate paste extrusion," Powder Technology, vol. 103, no. 2, pp. 103-109, 1999.

[56] J. Davies and J. G. P. Binner, "Plastic forming of alumina from coagulated suspensions," Journal of the European Ceramic Society, vol. 20, no. 10, pp. 1569-1577, 2000.

[57] L. Hongjun and M. C. Leu, "Liquid phase migration in extrusion of aqueous alumina paste for freeze-form extrusion fabrication," International Journal of Modern Physics B, vol. 23, no. 6-7, pp. 1861-1866, 2009.

[58] M. J. Patel, J. Wedderburn, S. Blackburn, and D. I. Wilson, "Maldistribution of fluids in extrudates," Journal of the European Ceramic Society, vol. 29, no. 5, pp. 937-941, 2009.

[59] K. A. Wickersheim and G. K. Korpi, "Interpretation of the infrared spectrum of boehmite," The Journal of Chemical Physics, vol. 42, no. 2, pp. 579-583, 1965.

[60] S. Ananthakumar, P. Manohar, and K. G. K. Warrier, "Effect of boehmite and organic binders on extrusion of alumina," Ceramics International, vol. 30, no. 6, pp. 837-842, 2004.

[61] H. N. Yoshimura, A. L. Molisani, N. E. Narita, P. F. Cesar, and H. Goldenstein, "Porosity dependence of elastic constants in aluminum nitride ceramics," Materials Research, vol. 10, no. 2, pp. 127-133, 2007. 

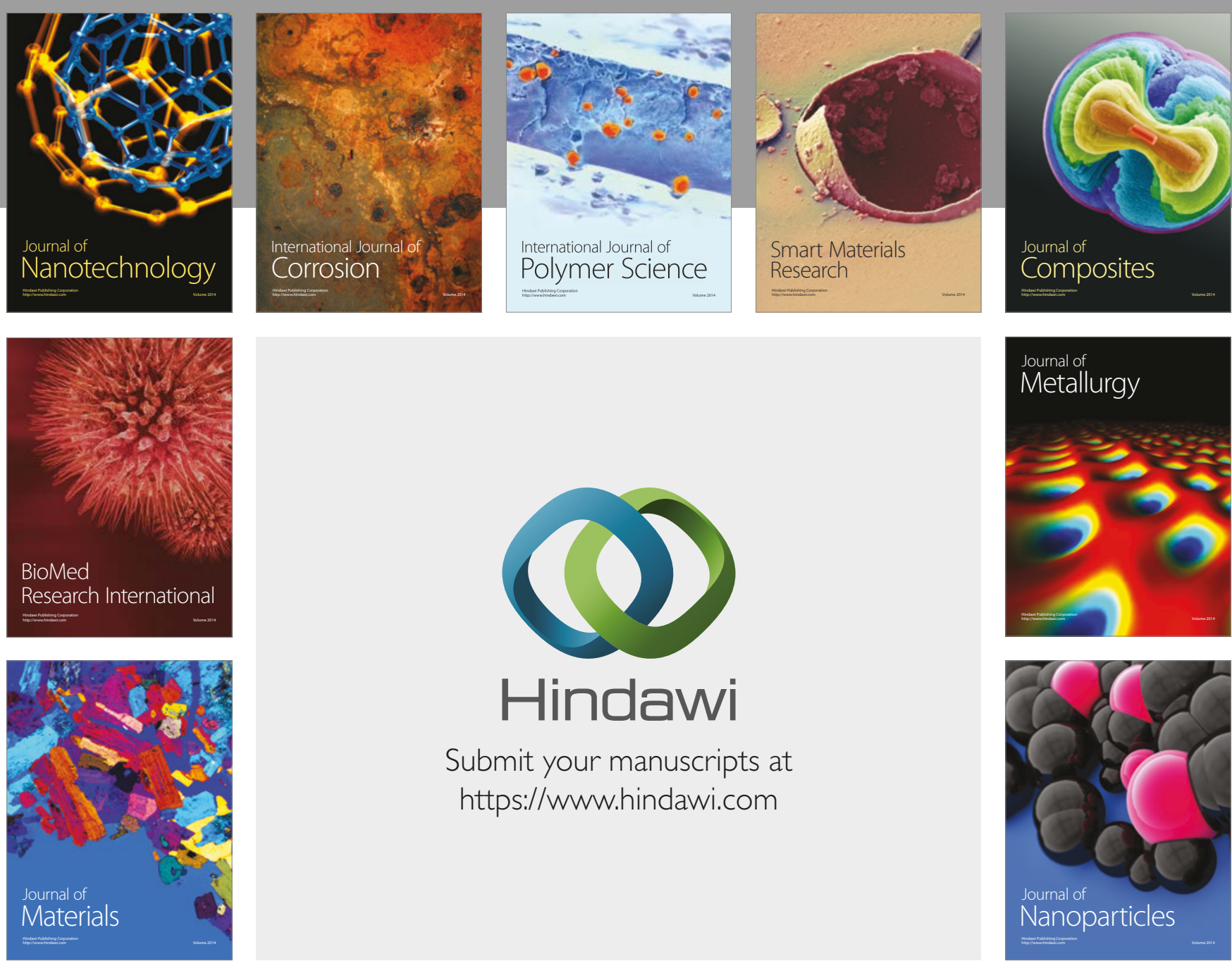

\section{Hindawi}

Submit your manuscripts at

https://www.hindawi.com
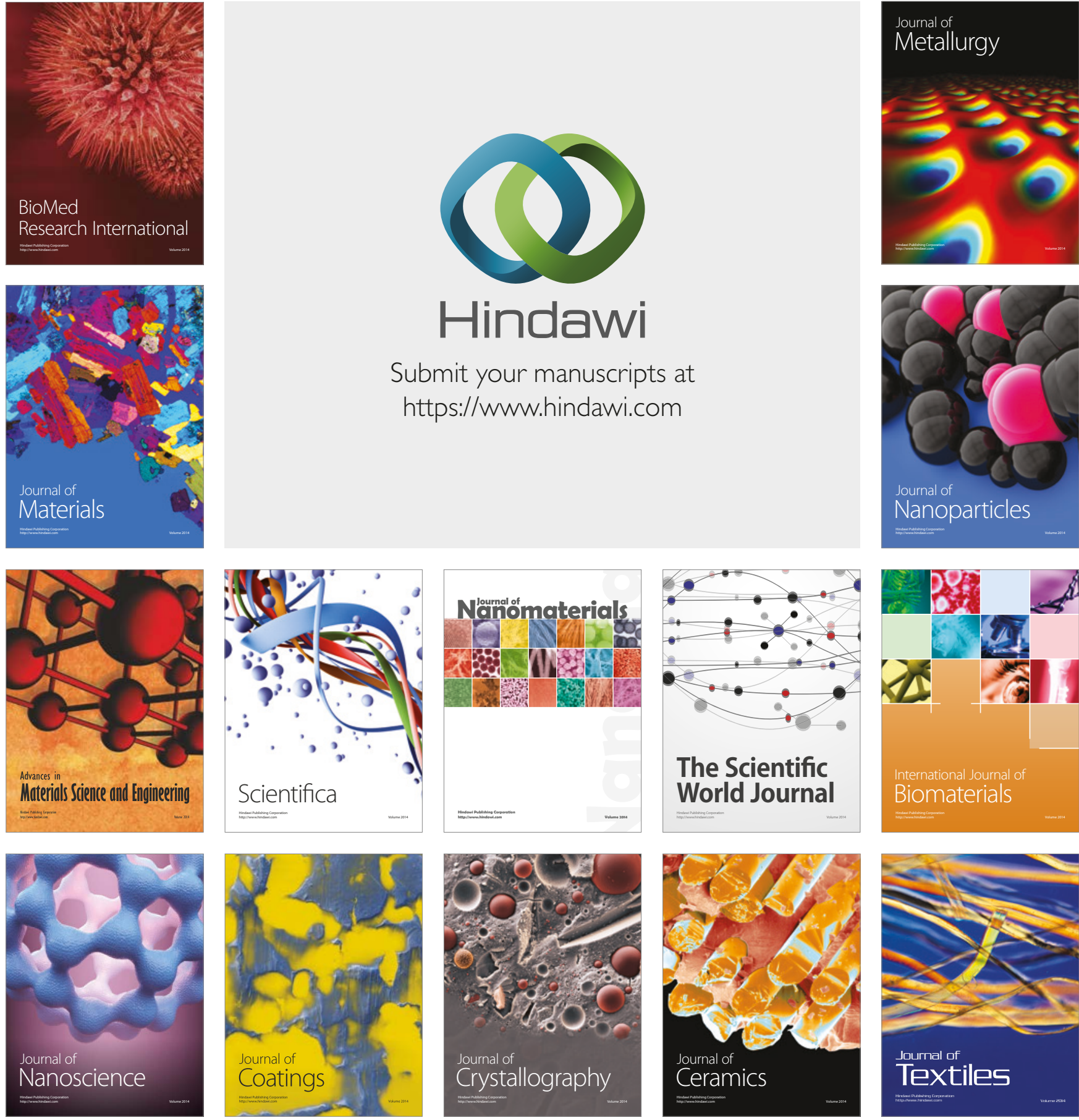

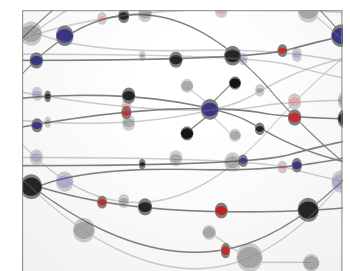

The Scientific World Journal
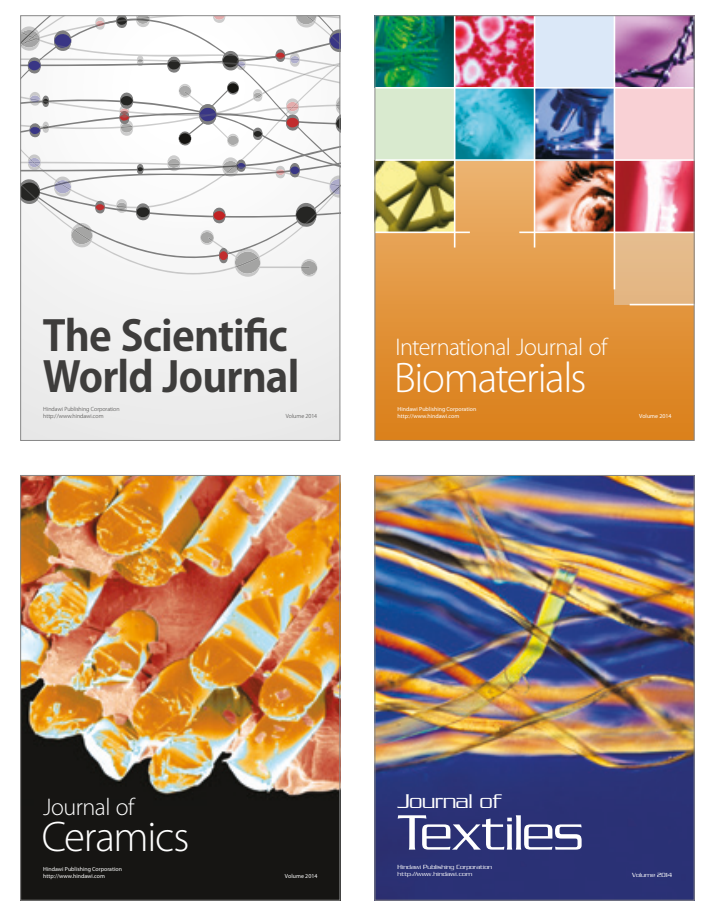